\title{
Sırta Bakış / Sırtın Bakışı: Sinemada Estetik Modernizm Bağlamında Sırt Takip Plan ${ }^{1}$
}

\author{
Tülay ÇELIK*
}

Özet

Bu makale, sinematografik bir biçim olaraksırt takip planın, estetik boyutta modernizm ile kurduğu ilişkiyi analiz etmeyi amaçlamaktadır. Michel Foucault'ya göre estetik modernizm süreci biçimlerin ön plana çıkmasıyla başlar. Foucault'nun Édouard Manet ve René Magritte resimlerini analiz eden çalışmaları, bakışın niteliği ve bakış ilişkilerindeki değişimle bağlantılı olan ifadesizlik-belirsizlik, yüzeydüzlük ve yer değiştirme temalarnmı klasik temsili nasıl bozdu ğunu ortaya koyar. Estetik modernizmin nitelikleri olarak da tanımlanabilecek bu temalar, klasik sinema ile modern sinema arasındaki ayrm da açılayabilecek bir bağlantı sunar. Klasik sinema, gerçekliğin izlenimini sinematik teknikleri işlevsel olarak kullanarak kurar ve bu yönüyle Rönesans dönemindeki mimetik temsil biçimine eklemlenir. Buna karşın, estetik modernizm ile ilişkilendirilebilecek modern sinema, sinematik tekniklerle filmin maddi evrenini vurgulayarak zihinsel süreçleri ortaya çıkarır ve bir özgürleşme alanı yaratır. Bu çerçevede, yüzü ve bakışı saklayan, engelleyici, belirsiz, ifadesiz, düz bir form olan sırtın etkisini yoğunlaştıran ve onu özerk hale getiren sırt takip planlar, estetik modernizmin resim alanındaki nitelikleriyle güçlü bir ilişki kurar. Buradan hareketle bu çalışmada sırt takip planlar, Ahlat Ağacı (Nuri Bilge Ceylan, 2018) filmi odağında ifadesizlik-belirsizlik, yüzey-düzlük ve yer değiştirme temalarn ekseninde niteliksel olarak analiz edilmiştir.

Analiz sonucunda; yansıtıcı olan, yüzey etkisini güçlendiren, benzeyiş yerine andırış üzerinden ilerleyen sırt takip planların, eksikliğin yarattığı boşluk ile bakışım alanı kurduğu; karşılaşma anları yarattığ $\imath$; görülmeyeni harekete geçirdiği; bakış alanlarının sürekli değişmesine neden olarak seyircinin konumunu sorgulattığı; tamamlanmamışlığı ve bilinemezliği ile seyircinin beklentilerini boşa çıkardı ̆̆g görülmüştür. Sonuç olarak Ahlat Ağacı filmindeki sırt takip planlar, filmin mekanının çözülmesine, filmin maddiliğinin açı̆̆a çıkmasına neden olmakta; sırtın zamansız mekanında yeni düşünceler yaratılmasına imkan vermektedir.

Anahtar Kelimler: estetik modernizm, sırt takip plan, sinemada bakıs, modern sinema

ORCID ID : https:/ / orcid.org/ 0000-0002-8277-3386

E-mail : tcelik@sakarya.edu.tr.

DOI: $10.31122 /$ sinefilozofi.737140

Geliş Tarihi - Recieved: 14.05.2020

Kabul Tarihi - Accepted: 05.06.2020

\footnotetext{
${ }^{1}$ Bu çalışmada fikir düzeyinde, 2. Ulusal Sinema ve Felsefe Sempozyumunda sunulmuş olan “Film Görüntüsünün Sınırları: Sırt Takip Planda Seyircinin Bakışı" başlıklı bildiriden yola çıkılmış; fakat kavramsal çerçevesi değiştirilerek ve içeriği genişletilerek makale olarak yeniden yazılmıştır.
} 


\title{
Gaze in Back / Gazing Back: Tracking Shot From the Back Within Cinematic Aesthetic Modernism
}

\author{
Tülay ÇELIK**
}

\begin{abstract}
This article aims to analyze, in an aesthetic context, the relationship between modernist tropes and the usage of the tracking shot from the back as a cinematographic form. According to Michel Foucault, the aesthetics of modernism first emerge in forms carried to the foreground. Foucault's analysis of the paintings of Édouard Manet and René Magritte reveal how themes of expressionlessness-uncertainty, surface-flatness and displacement, all linked to the alterations in the characteristics of the gaze and gaze relations, break down the traditional in representation. These themes, which can be defined as indicative of the qualities of aesthetic modernism, also offer a possibility to demonstrate the distinction between classical and modern cinema. Classical cinema establishes the impression of reality by using cinematic techniques functionally and is thereby linked to forms of mimetic representation that emerged in the Renaissance period. On the other hand, modern cinema, in direct relation with aesthetic modernism, reveals mental processes by emphasizing the material nature of the filmic reality through cinematic techniques, thus creating a space for emancipation of viewer. In this respect, tracking shots from the back indicate a strong relationship with the qualities of aesthetic modernism also seen in painting. As the face and its expression are hidden, the preventive, uncertain, expressionless, flat form of the back is intensified. Furthermore, the study analyzes, tracking shots from the back using qualitative research methods with the central themes of expressionelessness, uncertainty, surface-flatness and displacement.
\end{abstract}

As a result of the analysis, tracking shots from the back, being reflective, strengthen the surface effect, prefer similitude rather than resemblance, by creating a space for the gaze through a gap that lacks, also creating moments of encounter that evoke the invisible thereby altering the point of view of the spectator, leading to an interrogation of their positionality. The reason why these shots don't meet viewer's expectations turns out to be reliant on their incomplete and obscure nature. As a result, the tracking shots from back in The Wild Pear Tree (Nuri Bilge Ceylan, 2018) unravels the filmic space, revealing the materiality of the film; it allows to create novel ideas within the timeless space of the back.

Keywords: aesthetic modernism, tracking shot from the back, gaze in cinema, modern cinema

ORCID ID : https://orcid.org/ 0000-0002-8277-3386

E-mail : tcelik@sakarya.edu.tr.

DOI: 10.31122/sinefilozofi.737140

Geliş Tarihi - Recieved: 14.05.2020

Kabul Tarihi - Accepted: 05.06.2020 


\section{Giriş}

Bu makale, sinematografik bir biçim olarak sırt takip planın, estetik boyutta modernizm ile kurduğu ilişkiyi analiz etmeyi amaçlamaktadır. Benzetme ve taklide dayalı ${ }^{1}$ sanat anlayışına karşı olan estetik modernizm, ${ }^{2}$ doğadan değil zihindeki imgelerden yola çıkar ve sanatın kendi gerçekliğini kurmasını sağlar (Artun, 2013: 13-44). Michel Foucault'ya göre bu süreç, sanatta biçimlerin ön plana geçmesiyle başlar. İlk kez Édouard Manet'nin resimlerinde belirginleşen biçimler, bakışın özgürleşmesi ile klasik temsil (re-présentation) ${ }^{3}$ alanındaki rollerinden siyrılır ve mekansal yanılsamayı ortadan kaldırır. Onun resimlerinde derinlik duygusunun engellenmesi, soyutlama ve yüzey etkisi, tablonun önü ve arkasının mevcudiyetinin vurgulanması, tuvalin tekrarı, rastlantısallık, tamamlanmamışlık, bakışın talebi ve reddi temsili yapıyı bozar. Foucault' ya göre, daha sonraki dönemde belirgin biçimde temsil ile oynayan isim, René Magritte'dir. Magritte' in resimlerinde benzeyiş yerine andırış tercih edilir, maddesellik çoğaltılır ve tablonun mekanı çözülür. Foucault'nun bu çalışmaları incelendiğinde, temelde bakışın niteliği ve bakış ilişkilerindeki değişimle bağlantılı olarak klasik temsili bozan ifadesizlik-belirsizlik, yüzey-düzlük ve yer değiştirme temaları ortaya çıkar. Estetik modernizmin nitelikleri olarak da tanımlanabilecek bu temalardan hareketle klasik sinema-modern sinema ayrımına geçilebilir. Çünkü bakışın değişimi ile biçimlerin, Serdar Öztürk'ün (2018) ifadesiyle sinematik tekniklerin (98) ön plana çıkması, sinemada da zaman-mekan ${ }^{4}$ boyutunda bir değissim yaratır. Klasik sinema, gerçekliğin izlenimini sinematik teknikleri işlevsel olarak kullanarak Rönesans dönemindeki mimetik temsil biçimine eklemlenirken, estetik modernizm ile ilişkilendirilebilecek modern sinema, sinematik tekniklerle klasik temsili bozar; filmin maddi evrenini vurgular ve bir özgürleşme alanı yaratır.

Resim ve sinema arasında, estetik modernizm izleğinde kurulabilecek bağın başlıca bileşenlerinden birinin sırt imgesi olduğu söylenebilir. Çünkü sırt da, temelde bakış ile kurulan ilişkinin dönüşümüne referans vermektedir. Sırt imgesi, hem resim hem sinema için düz, yüzey etkisine sahip, ifadesiz, belirsiz ve seyirciyi konum değiştirmeye zorlayan bir imgedir. Sinemada sırt, yüzü dolayısıyla bakışı saklayan ve aynı zamanda donuk yüzeyiyle seyircinin bakışını da yansıtan bir görüntüdür. Bu nedenle bakışlar arasındaki çatışmalı ilişkinin en belirgin olduğu imgedir. Sırtı hareketli bir çerçeve ile sunan sırt takip planlar ise, devinim sayesinde bu ifadesiz, belirsiz ve yansitıcı sırt imgesini daha etkili ve özerk hale getirir (Metz, 2012: 22). Bakışın yokluğu ya da bakış ilişkilerindeki kopukluk, görüntünün belirsizliği ile birlikte düşünümsellik zeminini yaratır (Orr, 1997: 84- 92); ortaya çıan bu modern sinematik deneyim, yeni düşünceler üretme potansiyeline sahip olur (Öztürk 2018: 53). Çizilen çerçeveden hareketle bu makale, modern sinemadaki sırt takip planların estetik modernizmin nitelikleri ile kesiştiği noktaları kavramaya; bu bağlamda bakış ile sırt görüntüsü arasındaki ilişkinin bileşenlerini analiz etmeye çalışmaktadır. Böylelikle, sırt takip planların estetik modernizm ile hangi düzeyde ne şekilde ilişki kurduğu; film evreninin zihinsel yapısının oluşmasına bu ilişkinin nasıl katkı verdiği tartışılabilecektir.

\section{2. Çalışmanın İzleği ve Yöntemi}

Estetik modernizm ve sırt takip plan ilişkisinin kavranabilmesi için, hem resimde hem sinemada biçimlerin işleyişinin araştırılması önemlidir. Foucault'nun vurguladığı gibi,

${ }^{1}$ Realist ve natüralist sanat.

${ }^{2}$ Illk kez Charles Baudelaire ile ortaya koyulan kavram, çok anlamlılığı, anlamsızlığı, karmaşıklığı ile zamanı ve mekanı parçalayarak özgürleşmeyi ve özerkleşmeyi sağlayabilecek, benzetmenin yerini ifadenin aldığı bir sanat alanin tanimlar (Artun, 2013: 10-57).

${ }^{3}$ Bazı yaklaşımlara göre Türkçeye "temsil" olarak çevrilen Fransızca "re-présentation" kelimesi, Antik Yunan döneminden 19.yüzyıla kadar olan klasik sanat için kullanılan ve mimesisi ifade eden bir kavramdır. Bu makalede klasik temsil olarak ifade edilmiştir.

${ }^{4}$ Deleuze'e (2003) göre, hareket-süre blokları yaratan sinemanın çizgi-renk blokları yaratan resim (21) ile ilişkisi "mekan-zamanlar yaratma düzeyinde gerçekleşir." (23). Bu yaklaşım, çalışmanın resim-sinema ekseninde kurmaya çalıştı̆̆ bağlantıyı destekler niteliktedir. 
biçimler üzerine düşünülmesi, söylemin ve figürün karş1lklı işleyişlerinin betimlenmesini, iç içe geçen ilişkiler ağının anlaşılmasını ve böylelikle sanat eserlerinin kültürel bağlamı içinde kavranabilmesini mümkün kılar (Foucault, 2006: 221-223). Bilinçli düşünceden çok düşüncenin içsel bileşenlerinin açığa çıkarılması üzerinde duran Foucault, birbirinden bağımsız gibi görülen küçük bileşenlere dair açıklamaların bu bağlamda önemli olduğunu düşünür (Gutting, 2010: 61-74). Bir filmin, sistemsel ilişkiler bütünü içinde kavranabilmesi için filme özgü biçimsel öğelerin söylem ile ilişkisi üzerine düşünülmesi önemlidir. Christian Metz'in (2012), sinemada uzun süre devam etmiş olan içerik ve biçim tartışmalarını ele alırken sinematografik olanın yalnızca biçim olabileceğinin altını çizmesi, bu yaklaşımı destekler niteliktedir (94)..$^{5}$ Benzer biçimde, Öztürk'ün (2018) belirttiği gibi, sinemanın hareket zaman bloklarıyla, bir fikri tamamen "kendine ait tekniklerle ve kendi tarzında ve de yeni düşünceleri üretecek biçimde" işlediği hatırlanmalıdır (53). Seyircinin film ile ilişkisini belirleyen biçimsel yapı, teknik ve estetik tercihlerle görünür olur.

Foucault'nun vurguladığı gibi, niteliği itibariyle eleştirel bir yaklaşım olan modernitenin, sürekli bir dönüşüme referans vermesi (Gutting, 2010: 91), biçim ve modernizm ilişkisinin yapıları açığa çıkaran zamansız bir bağlantı olarak kabul edilmesini mümkün kılar. Sırt takip planın eleştirel ve özgürleştirici kullanımlarının estetik modernizm ekseninde ele alınması, zamanın sınırlarını aşan bu bağlantının yeniden değerlendirilmesine imkan verir. Bununla birlikte, sırtı izleyen kameranın takip hareketi, bir arayışı andırmaktadır. Bu nitelik, modern sinemada $^{6}$ sürekli devam eden kişinin kendini keşfetme arayışı ile ilişkilendirildiğinde (Orr, 1997:24), modernite ile kurulan bağlantıyı destekler. Bu bağlamda sırt takip planların çok

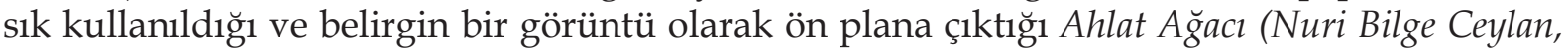
2018) filmi, örneklem olarak seçilmiştir. Yüzü ve bakışı saklayan, engelleyici, belirsiz, ifadesiz, düz bir form olan sırtın etkisini Ahlat A ̆gacı filminde açığa çıkaran ve yoğunlaştıran sırt takip planların, Foucault'nun analizinden hareketle estetik modernizm ile ilişkilendirilebileceği düşünülmüştür.

Jean Louis Comolli, herhangi bir teknik aracın filmin içindeki işlevini çözümlemek için diğer sanat alanlarının sinematik olmayan kodlarından faydalanılması gerektiğini belirtir. Resim sanatının biçimsel kodları ile filmin sinematografik nitelikleri arasındaki ilişki de, mekan ve zaman boyutundaki değişimin kavranmasına katkı verecektir (Bordwell, 1997: 160). $\mathrm{Bu}$ çerçevede, filmdeki sırt takip planlar, çalışmada estetik modernizmin nitelikleri olarak ön plana çıkan ifadesizlik-belirsizlik, yüzey-düzlük ve yer değiştirme temaları ekseninde niteliksel olarak analiz edilmiştir. Analiz kısmında, çalışmanın kavramsal çerçevesi ile uyumlu olarak, imgelerin mimetik benzerliğinden değil, imgelerin temsilden vazgeçiş bağlamından yola çııılmasına dikkat edilmiştir.

Makalede sırt takip planları analiz edebilmek için öncelikle, Foucault'nun, estetik modernizm perspektifinde Manet'nin resmini değerlendirdiği metni Manet'nin Sanatı (1971) ile Magritte'in resimlerini incelediği Bu Bir Pipo Değildir (1973) adlı çalışması ele alınmış, böylelikle çalışmanın kavramsal çerçevesi çizilmiştir. Ardından makaledeki temel bağlantılarının kurulabilmesi için klasik sinema ve bakış ilişkisine değinilmiş; sinemada estetik modernizm kavramı incelenmiş; modern sinemanın özellikleri ortaya koyulmuştur. Teknik bir öge olarak sırt takip plan ve onun uzlaşımsal kullanımlarına değinildikten sonra, sinema ve resim alanından örneklerle sırt imgesi ele alınmıştır. Bu kısımda, estetik modernizm ve bakıș ilişkisi, Jacques Lacan'ın "gerçek" kavramı ile bağlantılı olarak değerlendirilmiştir.

\footnotetext{
${ }^{5}$ Kitabın ikinci cildinden alınmıştır.

${ }^{6}$ Açıktır ki modern sinema / modern anlatı kavramı birçok sinema kuramcısı ve felsefeci tarafından açılanmış; bu sinemanın nitelikleri farklı perspektiflerden değerlendirilmiştir. Ancak bu makalede, sırt takip plandan hareketle, Foucault'nun estetik modernizm kavramı ekseninde yeni bir bağlantı noktası bulunmaya çalışılmıştır. Makalenin sınırlılıkları nedeniyle, modern sinema yaklaşımlarına çalışmada detaylı bir yer ayrılmamış, yalnızca bazı kesişme noktalarında, çalışmayı destekleyen düşüncelere referans verilmesi ile yetinilmiştir.
} 
Son bölümde, estetik modernizmin nitelikleri olarak ön plana çıkan temalar ekseninde Ahlat A ̆̆acı filmindeki sırt takip planlar analiz edilmiş; sırt takip plan ve estetik modernizm ilişkisi çözümlenmeye çalışılmıştır.

\section{Foucault'nun Manet Resmi Analizi ve Estetik Modernizm Vurgusu}

Foucault'ya (2018) göre estetik modernizm, Manet ile başlar. Bunun en önemli sebebi, Rönesans'tan beri iki boyutlu olduğu halde üç boyutlu olduğu yanılsamasını yaratmış ve

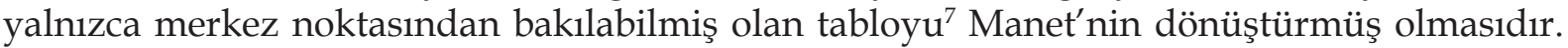
Bu dönüşümün sebebi, tablonun maddi özelliklerinin ön plana geçmesiyle nesne-tablonun açığa çıkmasıdır. ${ }^{8}$ Foucault, Manet'deki nesne tabloya üç nitelik sayesinde ulaşmıştır: tuvalin mekansal özelliklerinin vurgulanması, temsili ışık yerine gerçek ışı̆̆ın kullanımı ve seyircinin tablo karşısındaki konumu (11-13). Manet'nin tablolarında derinlik duygusu engellenir. Hacim ve yüzey hissiyle, mekanın hayali yapısı açığa çıkarılır. Resimlerde, dikey ve yatay konumlar ile tuvalin tekrarlanması; mekansal konumun ve kişilerin uzaklığının keyfi ya da simgesel olması önemlidir. Bu yatay ve dikey dokular aracılı̆̆ıyla soyutlama etkisi de yaratılır. Örneğin Le Balcon (Balkon, 1866-69) resminde arka planın görünmez kılınması ve derinlik hissinin engellenmesi ile figürler ara mekanda adeta asılı kalır. La Serveuse de Bocks (Bira Servisi Yapan Garson Kız, 1879) isimli tabloda, hem figürlerin baktıkları noktanın görülmemesi hem de ters yönlere bakıyor olmaları, tablonun önünün ve arkasının varlığını hatırlatır. Ayrıca resim, görünür olana değil görünmez olana işaret ederek seyirciye farklı konumlar önerir. Le Chemin de Fer (Demiryolu, 1872-73) tablosunda olduğu gibi, seyircinin konum değiştirme arzusunun tatmin edilmemesi ise huzursuzluk hissi yaratır (Görsel 1). Bu resimde, seyirci küçük kızın bakışını görmeyi arzular; fakat sırtı dönük figür, bakışını seyirciden saklar. Bakılan noktadan kızın yüzünün görülmesi imkansızdır. Foucault'ya göre burada tablo, yarattığı bakış alanları ile seyirciyi hareketlendirirken "görünmeyeni" göstermiş olur (Foucault, 2018: 19- 51). Hem kadının yüzü, hem küçük kızın sırtı, ifadesizlik ve belirsizlik alanıdır. Bakış, buraya hem davet edilir hem de buradan kovulur. Kızın baktığı yönü kaplayan sis, bakışın belirsizliğini artırdığı gibi derinliği de azaltır. Seyirciyi, tablonun yüzeyiyle ve düzleşme etkisi ile karş1 karşıya bırakır.

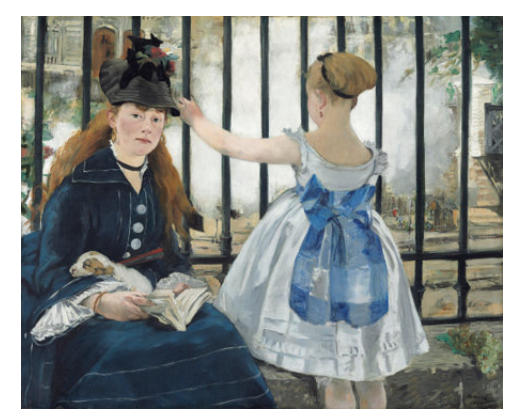

Görsel 1. Demiryolu, É. Manet, 1872-73

\footnotetext{
${ }^{7}$ Doğanın bir model olduğu düşüncesinden hareketle, taklit ve öykünme aracılı̆̆ıyla yansıtılmasını betimleyen "mimesis" kavramı ile ilk kez Antik Yunan döneminde karşılaşılır (Tunalı, 2001: 176-177). Rönesans döneminde bu yanılsama, merkezi perspektif yasaları aracılığı ile güçlendirilir. Belirlenen sistem ile dış dünyanın sabitlenmesi sağlanarak, gerçekliğin yansıtılabileceği düşünülür. Bu amaçla, özne için sabit bir bakış noktası tayin edilir; buradan hareketle mekansal yanılsama yaratılır. Tablonun seyredilmesi, önceden belirlenmiş bu bakışın benimsenmesi anlamına gelir. Gerçekliği görünüşe dönüştürdüğünü iddia eden simgesel biçim, norm ve akıl öncülüğünde dış dünyayı sınırlandırmış olur. Bu bakışın iktidar alanında, öznenin serbest iradesinden söz edilemez. Özne, burada kontrol edilebilir bir nesneye dönüşür (Panofsky, 2017:15-57).

${ }^{8}$ Foucault (2001), "şeyler" in kendi üzerlerine kapanmaya ve temsil alanındaki rollerini bırakmaya başlama sürecini (23), Kelimeler ve Şeyler adlı eserinde örneklerle ortaya koyar. Bu analizlerinde, metnin kendi anlatısının nesnesi haline geldiğini; kelimelerin anlamlarının değil, esrarlı ve geçici varlıklarının ön plana çıktığını, söylem olarak dilin reddedildiğini ve düşüncenin maddiliğinin ortaya koyulduğunu söyler (427-534).
} 
Micheal Fried'e göre Manet resminde, figürlerin yüzlerindeki ifadenin belirsizliği, seyircinin tabloyla bağlantı kurmasını zorlaştırır. Yüz hatlarındaki silinmişlik hissi, tamamlanmamışlık etkisi yaratır. Bu durum, mimetik yanılsamanın yaratılmasını engeller. Aynı zamanda yüzdeki duyguların belirsizleşmesiyle ortaya çıkan anlamsızlık, seyirciyle iletişimin kesilmesine; sahnenin kendi üstüne kapanmasına neden olur (Talon-Hugon, 2018: 80- 97). İfadesizleşen yüz, doğası gereği ifadesiz olan sırt ile benzerlik gösterir. İkisi de artık ayırt edici bir role sahip değildir.

Magritte'in resimleri, mekanın altında bir şey olmadığını göstermeye çalışır. Foucault'ya göre bu durum, bir tür bulunmayış halidir ve tablonun kendini yansıtmasına neden olur (Foucault, 2016: 40). Personnage Marchant Vers L'horizon / L'apparition (Ufka Doğru Yürüyen Kişi, 1928) ${ }^{9}$ resminde bulunan birtakım lekeler sırtın oluşturduğu leke ile ilişkilenir (Görsel 2). Bu kütleler, hacimleri olmasına rağmen belirsiz ve kimliksizdir (Foucault, 2016: 39). Her ne kadar resimde sırtından görülen kişi, bir insan figürü görünümüne sahip olsa da, diğer nesnelerin maddesel yüzeyinin açığa çıkması ile sırtın görünümü de bir belirsizlik alanı olur. Foucault (2016), Magritte'in klasik resimdeki benzeyiş ilkesi yerine andırışı tercih ettiğini vurgular. Benzeyiş, klasik temsilin hizmetinde bir benzerlik iddiası ve bir başvuru noktası sunar; andırış ise farklı yönlere hareket edebilen, yinelenebilen bir belirsizliği açığa çıkarır (43). Andırışlar

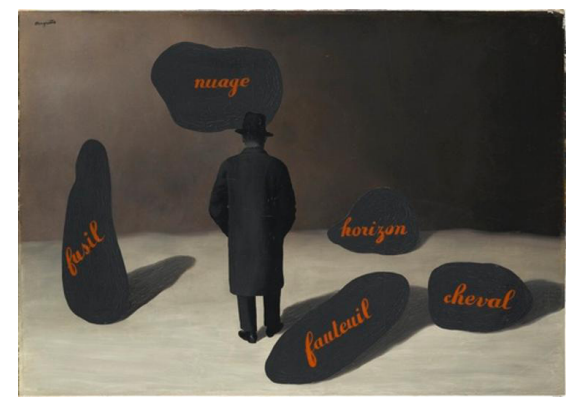

Görsel 2. Ufka Doğru Yürüyen Kişi, R. Magritte, 1928

aracılığ1 ile görüntü kimliğini kaybeder (50-51). Foucault'nun bu noktada ortaya koyduğu argüman dikkat çekicidir. Ona göre Magritte'in andırış üzerinden ilerlemeyi seçmesinin nedeni, dünyanın gerçekliğinin bulanıklık ve belirsizlik ile ilişkili olmasıdır (Foucault, 5859). Burada Öztürk'ün (2018) belirttiği gibi beynin çalışma yapısının yorum ve belirsizlik temelinde kurulduğu vurgulanmalıdır. Öztürk, Henri Bergson'a referansla beynin diş dünyayı algıladığında bir aralık açtığını dile getirir. Buranın nasıl doldurulacağı belirli değildir (90). Belirsizliğin dünyanın gerçekliği ile ilişkisinin vurgulanması makalede modern sinema ile sırt imgesinin ilişkilendirilmesi açısından önemlidir. "Ana akım sinema dışına çıkıldığında belirsizlik yoğunlaşır, alternatif olasılıklar, çatallanmalar, virtüel ve edimsel zaman ve mekânlar arasında gidiş gelişler yoğun yaşanır." (91). Öztürk'ün Citizen Kane (Yurttaş Kane, Orson Welles, 1941) filmiyle ilgili yorumunda, bu durumun sinemanın doğasından değil “yaşamın, ilişkilerin, beynin ve evrenin" işleyişinden kaynaklandığını belirtmesi, Foucault'nun ifadesini destekler niteliktedir (92). Bu anlamda sırt görüntüsü, bir aralık olarak bu gidiş gelişlerin ifşa alanıdır.

Foucault'nun Manet ve Magritte analizi değerlendirildiğinde, klasik temsilin bozulması ekseninde, bakış ile bağlantılı olduğu görülen yüzey-düzlük, ifadesizlik-belirsizlik ve yer

\footnotetext{
${ }^{9}$ Resim, yer aldığ 1 Stuttgart Galerisi kolekiyonunda L'apparition adı ile bulunmasına rağmen Foucault, incelemesinde Personnage Marchant Vers L'horizon ismini kullanır. Bu isim, Selahattin Hilav tarafından Ufka Doğru Yürüyen Kişi olarak Türkçeye çevrilmiştir.
} 
değiştirme olarak üç ana tema ortaya koyulabilir. Bu kavramların, sinemadaki sırt imgesi ile kurduğu ilişkiyi kavrayabilmek için öncelikle klasik sinema ve bakış ilişkisinin temel dinamiklerine değinerek sinemada estetik modernizm ve modern sinema kavramları ele alınabilir.

\section{Sinemada Estetik Modernizm: Klasik Sinemadan Modern Sinemaya}

Rönesans resmindeki benzerlik ilkesi gibi mimetik yapıdan kaynaklanan görüntünün sürekliliği ilkesi de klasik anlatı sinemasında gerçeklik yanılsaması üretir. Bu tür bir anlatı seyirciyi, merkezi, hayali ve aşkın bir konuma yerleştirir (Kırel, 2018: 215). Rönesans resmindeki yanılsama, sinemada filmin inandırıcılığının arttırılmasını sağlayan teknik tercihlerle yaratılır. Temel ilkeler çerçevesinde geliştirilen bu uzlaşımsal kurallar bütününü Noël Burch, IMR (Institutional Mode of Representation / Klasik Temsil Biçimi) olarak niteler. Klasik temsil biçimi, görülmez ve saydam bir tekniktir. Kolay anlaşılır, düz çizgisel, oyuncuların kameraya bakmadığı ve böylelikle seyircinin bakışının davet edildiği bu biçim, karakterle özdeşleşmeyi sağlar. Bunu yaparken ne görüldüğünü ve buna nasıl tepki verildiğini ön plana çıkarır (Bordwell, 1997: 96). Rönesans perspektifi, bu sinema için bir model olmuştur. Sabit bir noktaya göre nesnelerin düzenlenmesi, öznenin merkezi konumunu belirlemiştir (Baudry, 1986: 289). Rönesans perspektifi gibi kurgu kuralları da seyirciyi merkeze koyar. Burch'e göre, seyirci, kompozisyon, aydınlatma ve kurgu ile ekranın düzlüğünü unutur. KTB, gerçeklik yanılsaması sunar ve ideolojik olarak yönlendirilmiş bir deneyim yaşatır (Bordwell, 1997: 96). Klasik sinemada seyirci, kameranın bakışı ile özdeşleşir. Bu gizli nitelik, seyirciye kamera tarafından yönlendirildiğini unutturur (Elsaesser ve Hagener, 2014: 130). Comolli'nin (1974) "gerçekliğin izlenimi" olarak tanımladığı bu etkinin (28) yaratılması için "kameranın aksiyona bakışı" ve "seyircinin perdeye bakışı", "karakterin bakışı" ile birleştirilir. Böylelikle seyirci, kurmacanın içine girmiş olur (Elsaesser ve Hagener, 2014: 177).

Aygıt, özneyi anlamın kaynağıymış gibi hissettirerek onu bakışın efendisi kılar (Kırel, 2018: 215). Bu yanılsamanın temel kaynağı, Mulvey'in (2019) de belirttiği gibi görsel hazzın yönlendirilmesidir. Klasik sinemanın kodları, öznenin eksikliklerini, arzu ve korkularını da kullanarak onun için bir tatmin yanılsaması yaratır (204). Bu durumda, seyircinin bakışı, kodlar aracılığıyla kontrol edilmiş ve sınırlandırılmış olur. İzleyicinin tatmini, hem bakmanın hazzına hem de özdeşleşme ile denetleyen, iktidar kuran, erkek egemen bakışa sahip olması ile sağlanır (211). Bu nesneleştiren bakıştan kurtulmak için, kameranın ve seyircinin bakışının açığa çıkarılması, görünür kılınması önemlidir. Bu bağlamda sırt plan, seyircinin yanılsamalı tatminini ortadan kaldırırken filmin voyoristik (dikizlemeci) etkinlik ve edilginlik mekanizmalarını da yıkabilir (218). Mulvey'in kameranın maddeselliğinin görünür olması ve izleyicinin bakışının bağımsızlaşması ekseninde ele aldığı nitelikler (217-218), Foucault'nun Manet analizinde karşımıza çıkan estetik modernizmin nitelikleridir.

Bu çerçevede, sinemada modernizm, belirtilen sınırları aşacak olan biçimi ortaya koyma potansiyeline sahiptir. Klasik sinemayı sorgulayan ve dönüştüren eğilimler sinemanın ilk dönemlerinden beri görünür olmuştur. András Kovács'a göre (2010), dönemsel olarak modern dönem ürünü olan sinema, eleştirel kimliğiyle modernist hareketlerden ve ulusal kültürel mirastan yararlanarak modernizme eklemlenmiştir (17). Burada ön plana çıkan konu, estetik biçimin modern sanatın estetik niteliklerinden etkilenmiş olmasıdır. Öznellik, kendini yansitma ve soyutlama (54), sinemanın karakteristiğini belirleyen unsurlar olarak zamansiz bir sinema düşüncesini ortaya koyar. Bu sinema, modernizmde olduğu gibi “gelenekle eleştirelyansımalı bir ilişki içinde" (13) klasik olanla bir arada yaşar (40). Film dili çalışmalarını klasik olan üzerinden değerlendiren Burch da, sinemanın gelişimini modernizm ekseninde ele alır. Burch'e göre, 1906'ya kadar gelişen PMR (Primitive Mode of Representation /İlkel Temsil Biçimi), KTB tarafından baskı altına alınmıştır. Modernizm, bu ilkel biçimleri yeniden açığa çıarır (Bordwell, 1997:106). Bu argüman, Maurice Marleau Ponty'nin ilkel görme eylemi 
ifadesiyle benzerlik taşıması açısından çalışmanın ilerleyen kısımlarında, modernizm-sırtbakış ilişkisinin derinleştirilmesine imkan verecektir.

John Orr (1997), 1915-25 yılları arasını yüksek modernizm, 1958-78 yılları arasını da bu döneme bir dönüș olarak yorumladığından, bu ikinci dönemi neo-modern olarak kabul eder. ${ }^{10} \mathrm{Bu}$ aşamada, uyumsuzluk-uyum, belirsizlik-anlaşılırlık, sorgulama ve onaylamanın bir aradalığ 1 ile birliktebiçimin yüceltildiğini, anlatının ve kameranın gücü üzerine düşünüldüğünü belirtir (12-17). Zaman ve mekanın sınırları kaldırılır, görüntü parçalanır (81). Alternatifleri ve belirsizlikleri özellikle gösteren biçimler, seyirciye yer değiştirmesi ve düşünebilmesi için alan açar (Öztürk 2018, 91). Modernist estetiğin düşünümsel yansıtıcı katlama niteliği, ${ }^{11}$ biçimler aracılığıyla sahnelemenin kurmaca yapısını açığa çıkararak sorgular. Elsaesser ve Hagener (2014), Film Kuramı adlı kitaplarında, postmodern sürecin düşünümselliğin eleştirel doğasını değiştirmediğine işaret eder (145). Bu vurgu, çalışmanın temel çerçevesinin modernizm ile bağlantılı olarak belirlenmiş olması düşüncesini destekler. Modernizmin zaman sınırlarını aşan karakteristiği, sinemanın eleştirel kimliğinin bir parçasıdır. Benzer şekilde, Orr, Alexandre Austruc ve Gilles Deleuze tarafından modernizm, sinema dilinin son ürünü olarak görülür. Onlara göre, sinemada modernizm tarihsel bir olgu olmadığından, her zaman güncel kalacaktır. Deleuze'ün ${ }^{12}$ modern sinemayı bir zihinsel ilişki biçimi olarak görmesinin bu fikri güçlendirdiği söylenebilir (Orr, 1997: 45-47).

Bu noktada, modern sinemanın temsil ile hesaplaşmasını biraz daha detaylı açılamak önemli görülmektedir. Öztürk (2019b), sinemanın bir temsil olmadığını, "fiziksel yaşamda kaybolan varlıkları ve ilişkileri ifşa eden, onları görünür hale getiren, onları farklı tarzlarda hiç düşünülmemiş boyutlarıyla gösteren bir yaratım" olduğunu belirtir (8). Düşüncesini, Bergson, Deleuze ve Félix Guattari ile temellendirir: Bergson, imaj anlayışında köklü bir değişim yaratmıştır. Ona göre, evrende kendi gücü olan varlıklar değişim ve karşılaşmalar içindedir. Dolayısıyla, "Bergson'a göre her şey imajdır, çünkü her şey değişir. Değişmeyen sabit özsel bir entite yoktur." (6). Bilinç, değişim, karşılaşma ve etkileşimle oluşur. Bu nedenle, bilinç bir şeyin görünümünü algılayan -ve çoğunlukla- bir yanılsamaya ulaşan bir şey değildir. Bu bağlamda, temsil alanı da değildir (7). Deleuze'e göre de bilinç "uzay ve zaman bloklarında yer alır" ve etkileşim içinde oluşur (9). Bu nedenle, irrasyonel kesmeler, birbiriyle bağlantısız imajlar ve motor-duyu mekanizmamızı afallatan imaj akışına sahip olan modern sinema ile beynin yapısı ve işleyişi arasında temel bir ortaklık vardır. Bu ortaklık modern sinemanın kendi tarzında "düşünce üreten" bir alan olduğunu kanitlar (Öztürk 2018: 31). ${ }^{13}$ Bununla birlikte, beynin işleyiş̧i ile kurulan bu bağlantı, makalenin argümanlarından biri olan modernizmin estetik niteliklerinin zamansızlı̆̆ını da vurgular.

\section{Teknik Bir Öge Olarak Sırt Takip Plan ve Uzlaşımsal Kullanımı}

Modern sinemada teknik tercihlerin birbirlerinden farkl1; dönüştürücü, eleştirel, sarsıc1 etkileri vardır; fakat klasik sinemada teknik işlevlerin birtakım formüllerle belirlendiği söylenebilir. Uzlaşımsal kullanımda yani teknik bir işaretin ön plana çıkmadığı anlatılarda, sırtın perdede görülmesi gerçekliğin izlenimini artıran bir unsurdur. Sırt plan, çoğu

\footnotetext{
${ }^{10}$ Kovács (2010) sinemadaki modernizmi iki döneme ayırır. İlk dönemde, sinemanın teknik yanları ve biçimi temel odak noktası olmuştur. Dışavurumculuk ile başlayan bu süreç, fütürizm, gerçeküstücülük, dadacılık ve kübizm etkileri ile devam eder ve izlenimcilik ile içsel görünümleri de içeren bir boyuta varır (17-20).

${ }^{11}$ Elsaesser ve Hagener'in (2014) Film Kuramı isimli kitabında, "reflexive-reflective doubling" ifadesi düşünümselyansıtıcı katlama olarak Türkçeye çevrilmiştir (122).

12 Deleuze'e göre modern sinema, öznellik, yurtsuzlaşma, sanallık, sezgisellik, rastlantısallık, irrasyonellik ve oluş ile açığa çıkan bir zaman-imge sinemasıdır (Çelik, 2018: 67). Bu çalışmada, sıralanan kavramlara, Foucault'nun estetik modernizm ile ilgili çalışmaları ekseninde yer verilmiştir.

13 İmajlar, yanılsama mekanizmalarını ortaya çıkarma potansiyeline sahiptir (Öztürk, 2016: 5). Bu nedenle, sinemadaki hareket-zaman blokları, içimizdeki ve dışımızdaki mağaradan kurtulmamıza imkan verir (Öztürk 2019a).
} 
zaman işlevsel olduğu için görünmez olan kesme ve kamera hareketleriyle seyirciye filmin varlığını unutturur. Klasik anlatıda sırt; gizli, ikincil, seyircide oluşması beklenen etkileri (gerilim, merak, korku) güçlendiren bir niteliğe sahiptir. Görüntüde en sık karşılaşılan sırt kullanımlarından biri de, açı karşı açı tekniği ile yaratılır (Thomas, 2012a: 6-8). Bu planlar, bir karakterin sırtı ile oluşan ifadesizliğin diğer karakterin yüzü ile tamamlanmasını sağlayarak hikayenin anlaşılmasını kolaylaştırır; seyircinin karakterlerle yakınlık kurmasına hizmet eder; seyircinin merakını hem tetikler hem giderir.

İzleyici çekim [takip çekimi], kameranın karakteri izlediği bir harekettir. Takibi sağlayan bu çekim, kamera açısının ve konumunun değişmesi sayesinde çerçeve ile birlikte hareket etme, nesneye yaklaşma, geri çekilme, yanından, üstünden geçme imkanı verir. Sırt takip planda karşımıza çıkan en belirgin hareketler, kaydırma (konu hareket etmez), vinç, steadicam ve drone ile elde edilir. Vinç, steadicam ve drone çok yönlü bir hareket sunar. Sırt takip planda seyircinin dikkati, sırtı görülen karakterin üzerinde kalır. Kamera sırtın hareketine uyumlu olarak hareket eder. ${ }^{14}$ Sirt takip planda devam eden bir kamera hareketi sirasinda, görüntünün içerdiği enformasyon artar; nesneler daha canlı ve üç boyutlu görülür; devamlı değişen perspektifler oluşur; mekan yatay ve dikey olarak kesintisiz sunulabilir; mekanlar arası geçişler sağlanır. Ayrıca kamera, seyircinin hareketi yerine geçen bir devinim olarak görüleceğinden, seyircinin filmin evrenine dahil olma hissini artırır (Bordwell ve Thompson, 2012: 199-203). Bu hareket imkanı, bakışı çok daha fazla kışkırtır ve tatmin olma yanılsamasını güçlendirir. Hareket edebilen bakış, kontrol edebilme yetisine sahip olduğunu daha fazla hisseder. Sırtın hareketli bir kamera aracılığıyla takip edilmesi, seyirciyi yerlerle ve olaylarla ilgilenmeye davet ettiği gibi karakterle kurulan bağı da güçlendirir. Metz'in de belirttiği gibi seyirci, merkezi rolüyle her şeyi algılayan özne olur (Thomas, 2012a: 8). Uzlaşımsal sırt takip hareketi, özdeşleşme ve yanılsama etkisini güçlendirme niteliği ile ön plana çıkar.

\section{Resimden Sinemaya Sırt-Bakış-Modernizm İlişkisi}

Benjamin Thomas'ın Tourner Le Dos (Sırtını Dönmek, 2012) ${ }^{15}$ isimli kitabı, sinemada sırt imgesini kullanan filmlerle ilgili yapılan en kapsamlı çalışmalardan biridir. Kitapta yer alan metinler incelendiğinde, bunların çoğunun sırtın uzlaşımsal olmayan kullanımlarına odaklandığı görülmektedir. George Banu'nun (2001) resimde ve tiyatroda sırtı ele alan kitabı L'Homme de Dos (Sırtından Görülen İnsan), ${ }^{16}$ bu çalışmalar için önemli bir referans noktası olmuştur. Banu, sırtın şifreli bir şiire benzediğini ve varoluşu kristalize ettiğini söylerken bir taraftan sırtın metafor olarak kullanımını, diğer taraftan ise metafor olmayı reddeden ve bu yönüyle de moderniteye eklemlenen niteliğini vurgulamıştır (11-17). Sırt, modern dönemden önce de resimlerde yer almaktadır; fakat estetik modernist anlayış ile birlikte, sırt imgesi tablonun maddiliğini açı̆̆a çıkaran bir unsura dönüşmeye başlamıştır. Görüntünün ikilem ve belirsizlik alanı yaratan çift değerli niteliği bu resimlerde ön plana çıkmaktadır. Francis Bacon'ın Study From the Human Body (İnsan Bedeni Konulu Çalı̧̧ma, 1949) ${ }^{17}$ isimli tablosunda (Görsel 3) sırtından görülen figür, hem dünyaya kendini gösteriyor hem de kendini çekiyor gibidir. Tablodaki bu duruşların ikisi de mutlak değerini kaybetmekte ve seyirciyi göreceli bir durumun içine yerleştirmektedir. Bu resim, iki duruş arasında bir seyahati ve diyaloğu mümkün k1lmaktadır (18).

\footnotetext{
${ }^{14}$ Seyircinin kendini devinen bir nesne olarak algılaması Dziga Vertov'un Sine-Göz yaklaşımıyla ilişkilendirilebilir. Ayrıca, Walter Benjamin'in kameranın devinimi ile bilinçaltı arasında kurmuş olduğu bağlantı da burada hatırlanabilir.

${ }^{15}$ Tarafımca önerilen çeviridir.

16 Tarafımca önerilen çeviridir.

17 Tarafımca önerilen çeviridir.
} 


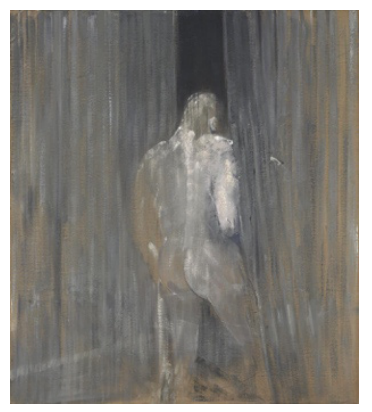

Görsel 3. İnsan Bedeni Konulu Çalışma, F. Bacon, 1949

Casimir Malevich'in resminde de olduğu gibi (Görsel 4) sırt, yüzden farklı olarak biricik olma durumunu ortadan kaldıran bir yapıya sahiptir. Sırtından görülen insan, tanımlı bir kimliği olmayan, kendi kişisel serüveninden özgürleşerek anonimlik içine yerleşen bir karaktere dönüşebilir. Sırtın donukluğu, aynı zamanda seyirciyi, hikaye ve varsayımlardan beslenen hayali bir kurguya sokar. Sırt, kesin cevaplara ulaşılmayacak olan gizemli bir delik gibi -bir ifade alanı olan yüzün aksine- maddenin dilsizliğine sahiptir. Banu'ya göre sırttan görülen insan, modern insanın habercisidir. Bu duruş, dünyaya arkasını dönme; var olan kurallardan kopma; başkaldırı ya da bir tür kınama olarak algılanabilir (23-28). Kodları bozan, onları aksatan, gedik açan ve istikrarsızlaştıran bir görünüm olarak sırt, bir tür özgürleşmedir (23-28). ${ }^{18}$ Örneğin Paul Delvaux'nun L'estacade (Dalgakıran, 1966) isimli tablosu (Görsel 5), tamamlanmamışlığı ortaya koyar. Birbirine yakın olan iki yabancı olarak resmedilen figürlerin birleşmeleri ve tamamlanmaları imkansızdır. Resim sanatında sık karşılaşılan kadınların sırtlarının ve ayna aracılığıyla yüzlerinin görüldüğü resimler, izleyiciyi her şeyi görmeye davet ederken Delvaux'nun tablosu, eksik birakmay1 tercih eder. Magritte'in La Reproduction Interdite (Çoğaltılması Yasaktır, 1937) adlı tablosunda (Görsel 6) genç adam, aynada kendine

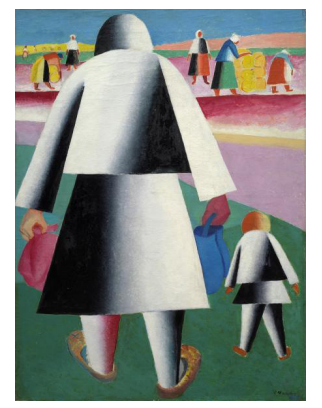

Görsel 4. Marpha ve Vanka, K. Malevich, 1930

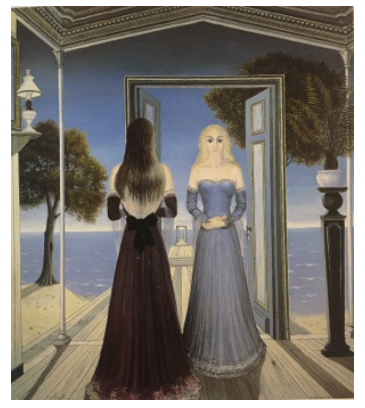

Görsel 5. Dalgakıran, P. Delvaux, 1966

bakar ama yalnızca sırtını görür. Görüntünün çelişkilerle anlamsız kılınması, benzerlik üzerinden ilerleyen temsili bozar (Harkness, 2016: 13). Andırış halindeki sırt, kendinden hareket eder, kendini çoğaltır ve kendine gönderme yapar. Sonsuz şekilde çoğalması, kimliğin kaybı demektir (Foucault, 2016: 51). Resimdeki kimliksizlik düşüncesinin etkisi, çoğaltılarak güçlendirilmiş olur. René Magritte'in Le Maitre d'école (Okul öğretmeni, 1955) adlı tablosunda

\footnotetext{
${ }^{18}$ Banu sırtın, görünüm şekli ne olursa olsun bir tabuya karşı geldiğini ve kanunun otoritesini yıktığını belirtir. Kutsal gözün gözetiminden kaçılamayacağının düşünülmesi nedeniyle, Rönesans dönemine kadar dini resim, sırtı görmezden gelmiştir (Banu, 2001: s.47).
} 


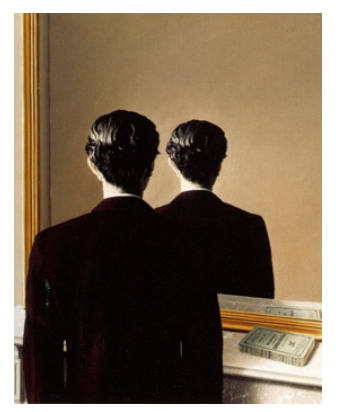

Görsel 6. Çoğaltılması yasaktır, R. Magritte, 1937

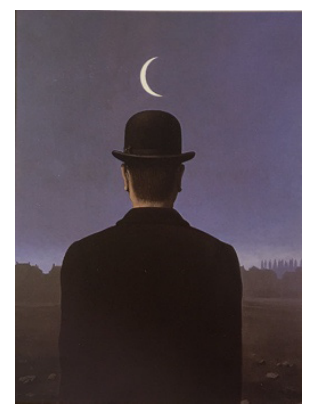

Görsel 7. Okul öğretmeni, R. Magritte,1955

(Görsel 7), yine zihinsel bir duruş ile karşılaşılır. Yüzü olmayan kahramanın tuhaflı̆̆1, tekinsizlik hissini açı̆̆a çıkarır; sorgulama yaratır (Banu, 2001: 150). Vilhelm Hammershøi'nın Intérieur avec Jeune Femme Vue de Dos (Evin İçinde Sırtı Dönük Kadın, 1903-1904) ${ }^{19}$ isimli resminde (Görsel 8) sırt figürü sayesinde yüzey ile oluş iletişim kurar. Kaçış perspektifi kurulmamış bu resim kendine gönderme yapar. Bu resimde bir kahraman olmadığ 1 anlaşılan bu figür, kabulleniş ve onaylama arasında gidip gelen bir çift değerliliğe sahip olur. Oluş halindeki bu duruş, tevekkül ve onay verme arasında çift değerliliğini devam ettirir. Tekrar etmeye başlayan sırt figürü, daha önceki klasik temsil biçimlerinden farklı olarak zihinsel bir duruş sergileyen bir figüre dönüşür (Banu, 2001: 132-148). Banu'ya göre "sırtın söylemi her zaman keşfedilecek durumdadır." (Banu, 2001: 158). Bu ifade, çalışmanın önceki bölümlerinde ele alındığı gibi, klasik temsilinin modernizmle bağlantısı içinde çözüldüğü, bu bağlamda sırt imgesinin zamanın sınırlarını aşan bir biçime dönüştüğü fikrini destekler.

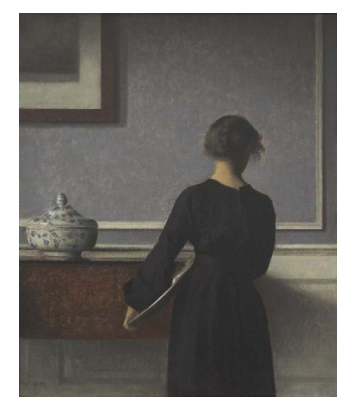

Görsel 8. Evin İçinde Sırtı Dönük Kadın, V. Hammershøi, (1903-1904)

Sinemada belirgin bir biçim olarak sırtın ön plana çıtı̆̆ filmlerden biri, Elephant (Fil, Gus Vant Sun, 2003) filmidir. Bu filmde, sahnelerin çoğu, koridor boyunca öğrencileri takip eden uzun çekimlerden oluşur (Görsel 9, 10, 11). Bir bilgisayar oyununu andıran sırt takip planın uzun süre devam etmesi, filmde sırtın otonom ve eleştirel bir öğe olarak belirmesine; bu sayede kontrol dişılığının vurgulanmasına hizmet eder (Thomas 2012a: 9). Sırtın bir yansıtma noktası $\mathrm{m} 1$ bir özdeşleşme aracı $\mathrm{m}$ olacağını belirleyen en önemli unsurlardan biri planın süresidir (Serceau, 2012: 20). La Petite Lise (Küçük Lise, Jean Grémillon, 1930) filminde yürüyen çiftin, arkalarından uzun bir süre boyunca takip edilmesi ve bu sırada konuşmaya devam ediyor olmaları, onların sırtlarını "seslerin yayıldı̆̆ı titreyen bir yüzeye dönüştürür"; burada yansıtma, sessel bir ekran yaratılmasını sağlar (Roger, 52).

\footnotetext{
${ }^{19}$ Tarafımca önerilen çeviridir.
} 


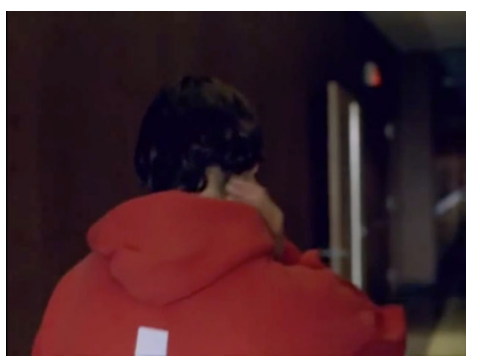

Görsel 9.

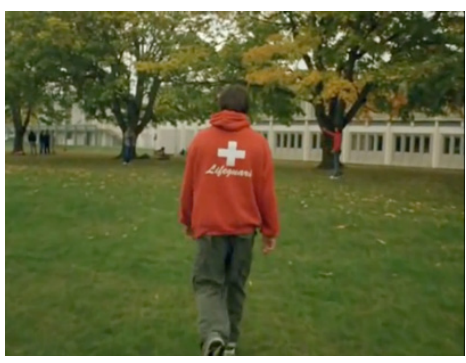

Görsel 10.

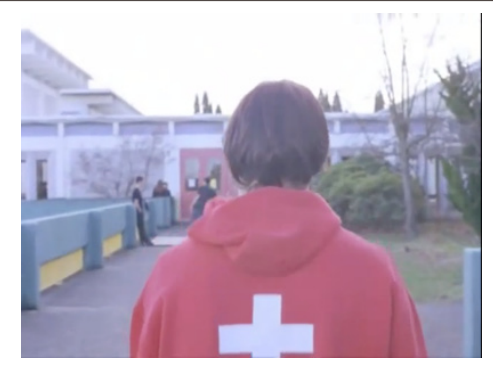

Görsel 11.

Fil, Gus Vant Sun, 2003

Sırtları konuşan yüzeylere çeviren bir diğer plan, Vivre Sa Vie (Hayatını Yaşamak, Jean Luc Godard, 1962) filmindedir (Görsel 12, 13). Arkalarından gördüğümüz geçirimsiz paltolu, blok halindeki sırtlar konuşur. Ekranı kaplayan bu yüzeyler izleyicinin bakışını engeller (Durafour, 2012: 67). Bu sahnede ses, yüzün eksikliğini görünür kılar. Bu eksiklik sirtları, seyircinin bakışını kontrol eden değil, bakışım alanı yaratılmasına imkan veren bir yüzeye dönüştürür. Benzer şekilde, Werkmeister Harmóniák (Karanlık Armoniler, Bela Tar, 2000) filminde karakterin sırtı $($ Görsel 14, 15) yansıtma ile ortaya çıkan bir belirsizlik alanı olarak filmin en temel unsuru olur (Thomas 2012a:9). Kavranılamaz olan dünyayı, belirsiz tehlikeyi ve tedirginliği, ekrandaki bir leke olarak sürekli hatırlatır.

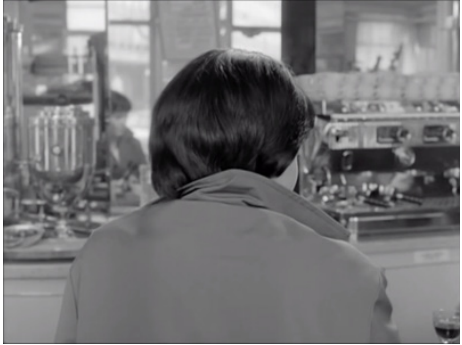

Görsel 12.

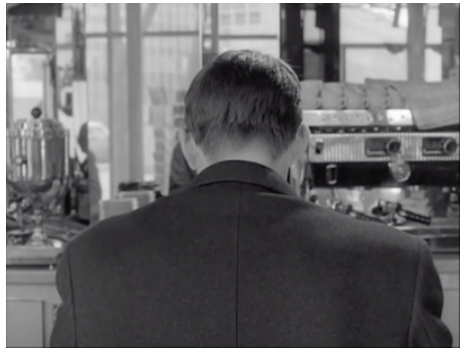

Görsel 13.

Hayatıı Yaşamak, J. L. Godard, 1962

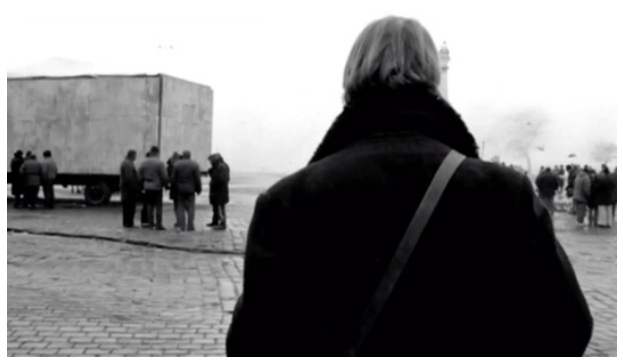

Görsel 14.

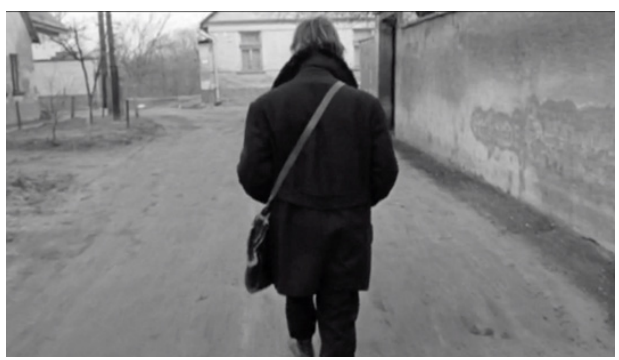

Görsel 15

Karanlik Armoniler, Bela Tar, 2000

Thomas tarafından, Aventura (Serüven, Michelangelo Antonioni, 1960) (Görsel 16, 17) ve L'Eclisse (Batan Güneş, M. Antonioni, 1962) (Görsel 18) filmlerinde Monica Vitti' nin (başrol oyuncusu) sırtı, benzer şekilde eleştirel bir düzenleme olarak görülür. Sırt imgesi sayesinde görüntü hem düz hem derin olur. Görüntü, bir taraftan perspektif kurallarına saygı gösterirken öte yandan yüzeyde çözülür. Thomas bunu, figürün iki farklı konumunun bakışı çatışmaya sokmasıyla ilişkilendirir. Vitti'nin adada pencereden baktığı sahne, bu görsel zitlığın bir 
örneğidir. Manzaranın görünümünün figür tarafından engellenmesi, derinlik illüzyonunu sağlayan kaçış noktasını başarısız kılar. Göz, sırtın bu siyah yüzeyine çekilir. Siyah ve net olmayan bir düzlük olarak sırt, seyircinin karşısındadır. Burada, figüratifin sorgulanması, soyutlamaya varmadan yine figüratif olan aracılığılla yapılır (Thomas 2012c: 169-172).

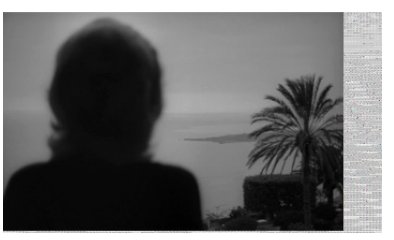

Görsel 16.

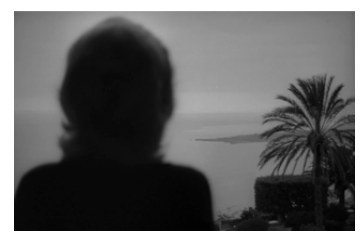

Görsel 17.

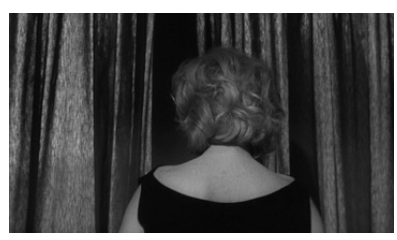

Görsel 18. Batan Güneş, M. Antonioni, 1962.

Serüven, M.Antonioni, 1960.

Sıralanan örneklerde sırtın uzlaşım dışı, temsili yapıyı ifşa ederek bozan nitelikleri görülebilir. Sırt takip plan seyircinin bakışını, karaktere değil sırta çeker. Sırt ise boşluğu, engelleyici duruşu ile görüntünün sınırlarını hatırlatır; görüntüyü estetik imgenin kendisine dönüştürür. Bu noktada, Lacan'ın "gerçek" kavramının sırt görüntüsü ile ilişkili olarak ele alınması sırt, bakış ve estetik modernizm bağlantısı açısından önemlidir. "İmgesel", "simgesel" ve "gerçek" olmak üzere üç temel düzeyden yola çıkan Lacan (2013), gerçek'i temsil edilen ile değil "temsil olmayışla" ilişkilendirir. Buradan yola çıkıldığında sırt (yüzü saklayarak temsili eksik bırakması nedeniyle), gerçek ile karşılaşılabilecek bir görüntü olarak yorumlanabilir. Lacan'a göre özne, gerçek ile karşılaşması sürecinde meydana gelir. Bilinçdışının alanında beklemede olan gerçeklik karşılaşmalarla açığa çıkar. Bununla birlikte özne bu süreçte belirsiz kalır; çünkü yarılma, kopuş, tereddüt ve eksiklik ile bulduklarını her an kaybedip, elinden kaçırıp yeniden başka şeyler bulabilir. Sırtın bakışı eksik bırakan görüntüsü de, bu bağlamda algı ile bilinç arasındaki zamansız boyutun açığa çıkmasına imkan verebilir.

Lacan'ın bakışa gizlice hükmettiğini söylediği ve öznenin görme eyleminden önce var olduğunu belirttiği leke gibi (31-83), sırt da bazı sahnelerde bilinçli görme eyleminden kaçar ve birdenbire gerçek olarak karşımıza çıkar. Ponty'e göre özne, sadece gözüyle değil, bütünlüğü ile biçimi düzenler. Buradaki görme eylemi, her şeyden önce ilkel olarak vardır. Bu eylemi gerçekleştirmek için önseziyi harekete geçirmek, ilk noktada var olana gitmek gerekir (Lacan, 2013: 89-90). Bu çerçevede, Sayın'ın (2003) gözü yaratıcı bir alan; bakışı ise sınırlayıcı bir alan olarak tanımladığı hatırlanabilir (60-61). Göz ve bakış arasındaki bu ayrım, görme eyleminin bütünlüklü ve ilksel yapısına gönderme yapar. "İmgeyi görünmezleştiren ... boşluk, imge içinde açılan bir oyuktur, görünenden görünmeyene uzanır ve bakışın ardındaki göz bebeğini yerinden oynatır." (10).

Lacan'a (2013) göre, bir tabloda düzen getirici, yatıştırıcı etki, "bakıştan vazgeçmeyi, bakışı teslim etmeyi" içerir (109). Tabloya bakan kişi bakışını indirmek zorunda kalır. Lacan, perspektif (geometrik görme eylemi) ile de ilişkilendirdiği bu durumu, bakışın terbiye edilmesi olarak niteler (117). Burada görmenin bu sınırlayıcı boyutunun "görme alanının bize sunduğu “öznelleştirici kökensel ilişkiyi her yönüyle” ortaya koymadığını belirtir (95). Sayın (2003) da böyle bir bakışın imgenin çift değerliliğini yitirmesine neden olduğunu vurgular. İmgenin içindeki eksikliğin, yani kurucu boşluğun ortadan kalkması ile bakışım alanı yıkılır ve imge teşhirci bir niteliğe bürünerek pornografiye teslim olur (10-28). Bu süreç, bir denetim alanı yaratarak özneyi nesneleştirir. Benzer şekilde, seyirci uzlaşımsal bir sırt takip planda bakışını imgelerin simgesel düzeni ile birleştirmeye çalışan uygulamalarla karakterin sırtını takip eder 
ve nesneleşir. Bu nesneleştirmeden, imgenin bakışı kontrol etmeyi bırakması ile çıkılır (Sayın, 2003: 31-32). Görüntüdeki eksiklik özneyi özgürleştirir (McGowan, 2012: 29-48). Bu durumda uzlaşımı bozan sırt görüntüsü, bir özgürleşme alanı haline gelir. Lacan (2013), bakılıyor olmak ile bilincin oluşumu arasında ilişki kurar. Bu çerçevede tablonun içinde özneye bakan bir lekenin olması ve özneye yakalanmış gibi hissettirmesi gerçeklik düzeyini açığa çıkarabilir. Bu da özneyi bahsedilen tatmine yaklaştırır. Eksikliğin cisimleştirilmesindeki çarpıcı etki, bakışın hiçlikle karşılaşma anı ile yaratılır. Bu noktada, skopik dürtünün (bilinç için ifade edildiği gibi) belirsiz bir dürtü olması (91),,$^{20}$ sırt görüntüsünün belirsizliği açığa çıkaran niteliği ile ilişkilendirilebilir.

Sırtın bakışı olarak ifade edilebilecek olan, seyirciyle bakışım alanı yaratan bu bakış, imgeselin değil "temsil olmayışın" bir tezahürüdür. Bu nedenle, estetik deneyimin akışını bozarak filmin maddi yapısını açığa çıkarır (McGowan'ın 2012: 29-32). Ahlat A ̆̆acı filminin sırt takip planlarının sırt-bakış-modernizm arasında kurulan bu ilişkiler ağı ekseninde çözümlenmesi, film evreninin zihinsel yapısının nasıl kurulduğunun anlaşılmasını sağlayacaktır.

\section{Estetik Modernizm Eksenine Ahlat A $\breve{g} a c ı$ Filminde Sırt Takip Planların Analizi: Sırta Bakış / Sırtın Bakışı}

Ahlat A $\breve{g} a c$ filminin ana karakteri olan Sinan, üniversiteyi bitirdikten sonra evine döner; yazdığı romanı yayımlatabilmek için uğraşır. Bu süreç içinde bir taraftan ülke ve taşra gerçekleriyle karşılaşır, öte yandan babası ile ilişkisi üzerinden kendi gerçekliği ile yüzleşir. Film, ekonomik, toplumsal, kültürel bağlam içinde baba ve taşra ile kurulan ilişkiyi hayaller ve gerçeklerin iç içeliği / ayrılığı düzleminde gösterir. Filmin biçimi bu temalar ekseninde, hayatı sorgulamaya ve anlam üzerine düşünmeye yönlendirir. Bu çalışma, sırt takip planların klasik temsili bozan, düşünceyi harekete geçiren, film evreninin zihinsel yapısını açığa çıkaran niteliklerine odaklanmaktadır. Bu nedenle, olay örgüsü, karakterler, filmin sosyolojik, felsefi, psikanalitik bağlamı ve bunlarla ilişkili metaforlar analizin ana izleği içinde yer almaz. Çalışma, sırt takip planların biçimini, estetik modernizmin nitelikleri olarak belirlenen ifadesizlikbelirsizlik, yüzey-düzlük, yer değiştirme temaları ekseninde analiz etmektedir. İncelenen sirt görüntülerinde, bir ya da birden fazla tema görünür olduğundan ve birçok kesişme alanı oluştuğundan, analiz yapılırken plan içinde en belirgin olan temalardan hareketle görüntüler araştırılmaya ve yorumlanmaya çalışılmıştır. Seçilen sırt takip planlar, sırtın sabit kameranın hareketli, kameranın sabit sırtın hareketli ve hem sırtın hem kameranın hareketli olduğu planları kapsamaktadır.

Filmde, Sinan'ın telefon ile konuştuğu sekans (Görsel 19-24), sırtın kamera tarafından uzun süre takip edildiği en önemli görüntülerden biridir. Sırtı takip eden yedi farklı planının birleştiği bu sekansta, 2 dakika 16 saniye boyunca seyirci sırtı izler ve telefon konuşmalarına Sinan'ın sırtına bakarak tanık olur. Uzun süren bu takip, Edgar Morin'in belirttiği gibi sırt imgesini bir yansıtıcıya çevirir (Serceau, 2012: 20). Telefonda, işsizlik, taşra, arayış, çıkış alternatifleri üzerine yapılan konuşmalar, hâkî renkteki ceketin donuk yüzeyinden yansır. Burada sırt, politik, ekonomik ve kültürel bağlamın yansıtıldığı bir alan olarak konuşan bir yüzeye dönüşür. Sinan'ın yüzünü görmek isteyen seyircinin bakışı, sırtta kalır. Bu noktada, yüzün eksiliği ile imgede bir boşluk açıldığı söylenebilir. Görünmeyene doğru bakışı çeken boşluk, bir bakışım (Sayın 2003 :21) alanı kurulmasına imkan vererek estetik deneyimi bozar; filmin maddi evrenini hatırlatır. Bu hatırlatma, ülke ve taşranın gerçekliği, Sinan'ın ve gençliğin arayışı/çıkışsızlığı bağlamında seyircinin düşünce geliştirmesine imkan verir.

Bu sekansın önemli bir niteliği de, sırtın bir anlatıcı ve yönlendirici olarak görüntüde yer almasidır (Serceau, 2012: 24). Bu nedenle seyirci onu kaybetmek istemez. Bilinmeyen bir

\footnotetext{
${ }^{20}$ Skopik düzey, arzu seviyesindedir ve arzunun eksikliği “objet a” olarak bakışla simgelenir (Lacan, 2013: 112-113).
} 
hikayede (Sinan'a polis arkadaşının anlattıkları bağlamında Türkiye' deki gençlerin iş-işsizlik ikileminde karşılaştıkları/yüzleştikleri ülke gerçeklerinin belirsizliği ve değişkenliği içinde), Sinan' 1 sirtı bir referans noktası olur. Sinan' in hareket halindeki sırtı seyirciyi bir yandan bir seyahate davet eder; öte yandan geçirimsiz bir yüzey olarak seyirciyi dışarıda bırakır. Sırt,

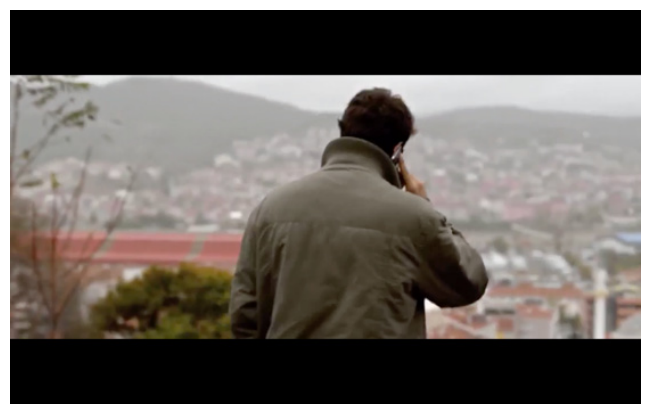

Görsel 19.

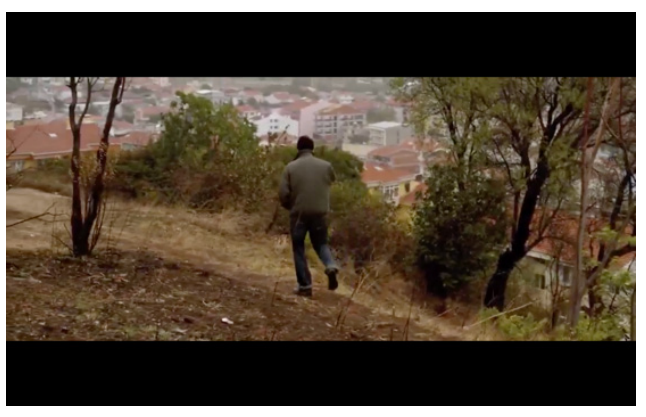

Görsel 21.

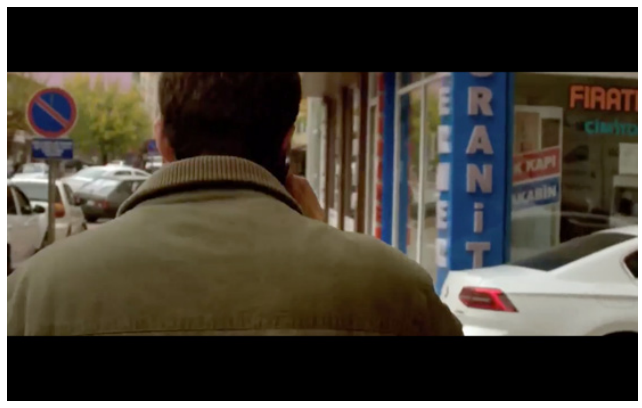

Görsel 23.

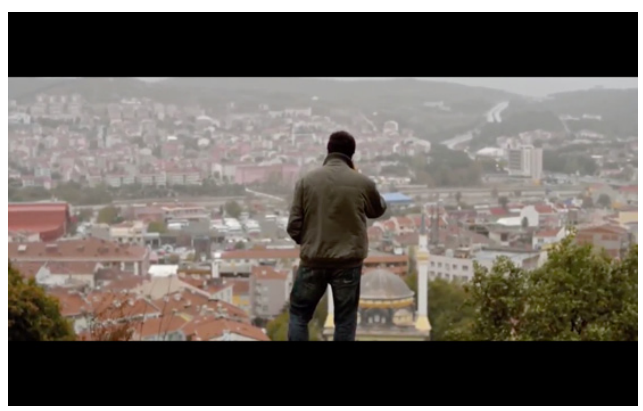

Görsel 20.

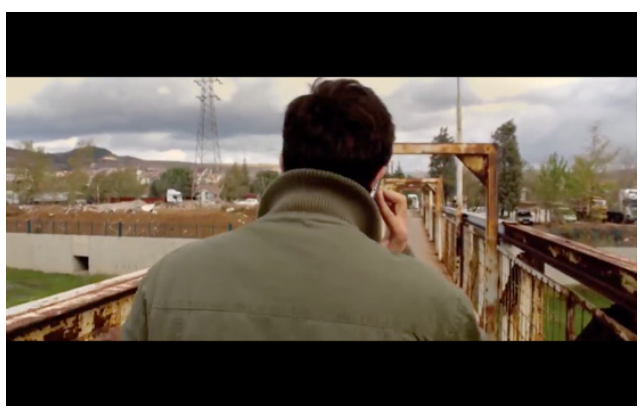

Görsel 22.

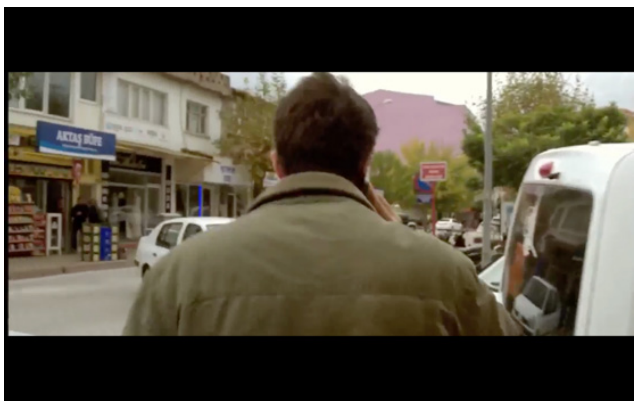

Görsel 24.

hem kendini gösteren hem de geri çeken bir imgeye dönüşür. Bu çift değerlilik, sırtı belirsizliğin alanı haline getirir. Sırt takip plan, hem seyirciyi içine alır hem de sırtın inatçı, düz, perspektifi bozan, dışarıda bırakan görüntüsüyle seyirciyi reddeder. Arkasını dönerek onu yüz üstü bırakır. Filmin davetkar evreninin büyüsüne kapılmışken sırtını dönen karakter, Manet'nin resmindeki, bakılmak üzere seyirciye dönen ama ifadesizliği ile seyirciyi reddeden donuk yüzleri hatırlatır (Talon-Hugon, 2018: 97). Tüm çıkış alternatiflerini kaybediyor görünen Sinan'ın sırt takip sahnesi, hem kendi dışlanmışlığının hem seyircinin dışlanmışlığının imgesi olarak kendi üzerine kapanır. ${ }^{21}$ Köprü üzerinde başlayan sırt görüntüleri, Fil filmindeki uzun

\footnotetext{
${ }^{21}$ Daniel Serceau'nun (2012), Saikaku Ichidai Onna (Oharu'nun Yaşamı, K.Mizoguchi, 1952) filmini ele alırken kadın karakterin sırtının görülmesi ile dünyanın bu kadına sırtını dönmesi arasında kurduğu ilişki, bu yorumun çııı̧
} 
takip sahneleri ile ilişkilendirilebilir. Oradakine benzer şekilde bir bilgisayar oyunundaki gibi kontrol edilebileceği düşünülen ama bakış ile egemen olunamayan sırt görüntüsü, belirsizlik hissi ile birlikte tedirginlik yaratır. Bu nedenle seyircide umutsuz bir yer değiştirme arzusunu da tetikler.

Sirt planda görülen karakter, bir taraftan sabit bir imge olarak güven hissi verirken öte yandan bir istikrarsızlık kaynağı olur. Bu durum, sırt imgesi sabitken çerçevedeki görüntünün ve mekanın değişmesi ile açıklanabilir. Bir tarafta mekandaki hareket öte yanda sabit bir imge vardır. Bakış ikisini de izler. Hem öndeki harekete odaklanma isteği hem de sırt tarafından sabit donuk bir imge ile engellenme duygusu ortaya çıkar. Seyirci, görülüp görülmediği ikilemi yerine, hem kontrolünde hem kontrolü dışında olan hareketin çelişkisini yaşar. Sürekli değişen belirsiz görüntüler nedeniyle oluşan istikrarsızlık ve bunun getirdiği huzursuzluk takip boyunca devam eder. Karakterin bakışı ile seyircinin bakışı arasındaki fark ve bunun uzlaşımsal yöntemlerle giderilmemesinin yarattığı huzursuzluk ve tamamlanmamışlık duygusu, anlatısallığı zayıflatır. Sırtın hareketiyle kurulan bu çatışmalar, filmin kurmaca yapısını ifşa eder.

Sinan'ın, babasının öğretmen arkadaşı ile karşılaştığı sahnede (Görsel 25) sırtın görüldüğü planda, kamera sabittir. Konuşma sırasında net alan önce öğretmenin üzerindedir. Bu sırada Sinan'ın sırtı, hem yüze sahip olmayan hem de net olmayan bir yüzeydir. Bu iki nitelik, sırtı çifte bir belirsizlik alanına dönüştürür. Sinan'ın sırtı, öğretmenin çerçeveden çıkışıyla netleşir. Sinan, konuşma bitiminde öğretmenin arkasından söylenir ve omuzunun üstünden geriye (kameraya doğru) bakar; ardından tekrar sırtını kameraya döner (Görsel 26). Bu sırada kamera sırta yaklaşır; Sinan, tekrar benzer şekilde geriye (kameraya doğru) bakar. Geriye bakış, babası ile olan ilişkisine de baktığı, geçmişine dönen bir bakıştır. Film burada

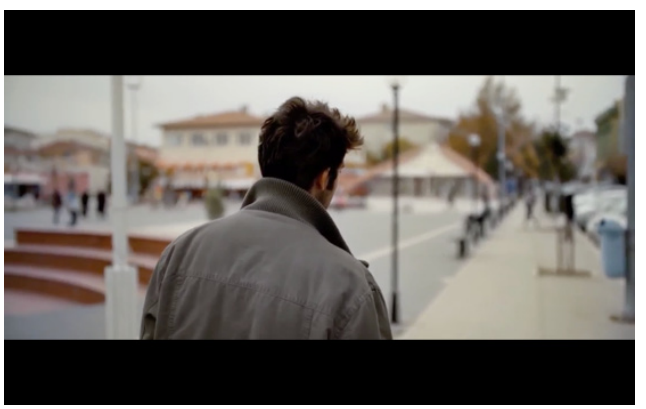

Görsel 25.

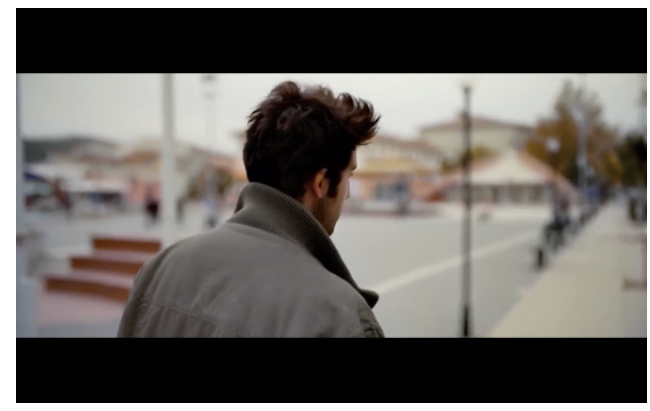

Görsel 26.

kendi üzerine kapanır. Sırt imgesi kendini, geçmiş ile şimdi arasında konumlanan, zamanı görünür kılan (Roger, 2012: 48) ikili bir varoluş alanı olarak sunar. Görüntüde gizlenen kör alan, görüntüde olmayanı harekete geçirir. Seyirci için buradaki sırt, hem psikanalitik hem de toplumsal bağlamda baba-oğul ilişkisinin görünür olduğu çarpıcı bir karşılaşma/yüzleşme alanı olarak, gerçek'i açığa çıkarır. Sayın'ın (2003) Roland Barthes'ın punctum kavramına benzettiği bu alan, geçmişin düşüncesini ve duygusunu görünür kılar (12). Bu çerçevede bu görüntü, Deleuze'ün zaman-imge kavramı ile de ilişkilendirilebilir. Thomas'ya göre (2012b), filmlerde yabancılaştırma ögesi olarak birdenbire seyirciye dönen bir yüz, temsil ile oynama imkanı verir; fakat temsilin istikrarını bozmaz. Çünkü orada bakışın mantığı devam eder. Yüzden farklı olarak sırtın gösterilmesi ise, filmi sarsacak bir etki yaratır (81-82). A ğlat A filmindeki bu sahnede büyük sarsıntıyı yaratan Sinan'ın konuşmasından sonra yüzünü

noktası olmuştur (28). 
dönerek seyirciye bakması değildir. Kameranın sırta doğru ilerlemesinin, gerçek ile karşılaşma anının dehşetini artırmasıdır.

Filmin son kuyu sahnesinde (Görsel 27, 28), Sinan sabit dururken, kamera onun sirtına doğru yaklaşır. Sinan'ın yüzünün görüldüğü bir önceki planla bu plan arasında, hareket devamlılığı sağlanmadığından bir uyumsuzluk vardır. Bu uyumsuzlukla yaratılan zamansal kopuş izlenimi, kamera Sinan'ın sırtına yaklaştıkça seyircinin tedirginliğinin artmasının da sebeplerinden biri olur. Diğer sebep ise, kameranın gizemli biçimde sabit bir figüre yaklaşma hareketidir. Sayın'ın (2003) belirttiği gibi "Hacmin içinde saklanan görünmezlik dehşet verici, tedirgin edici ve karanlıktır: ehlileştirmeye meydan okuyan, gözü yuvasından uğratan bir çeyiz barındırır" (23). Bu planda, sırtın hacmi içindeki görünmezliğin tedirgin edici ve karanlık yanı, belirtilen kamera hareketi ile açığa çıkar; klasik sinemanın gerçeklik izlenimi etkisini ortadan kaldırır.

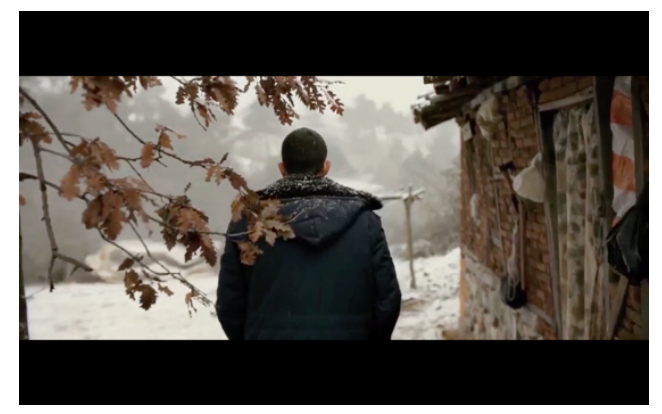

Görsel 27.

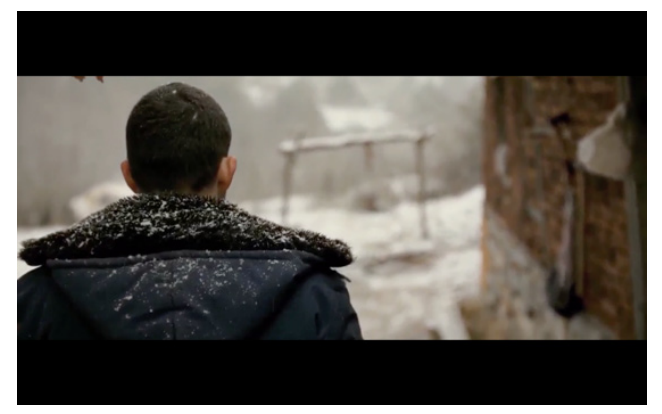

Görsel 28.

Belirsizliklerle ve tahminlerle gelişen yapı, tinsel bir iletişime geçilmesine imkan veren üstü örtük/sırtı dönük yapıdır. Bu planda sırt, izleyiciyi gören bir lekeye dönüşür. Görülemeyen fakat izleyiciyi gören leke (McGowan, 2012: 31) bakışın tehdit edici gücünü açığa çıkarır (Arslan, 2009: 27). Bu bakışma, filmin ele aldığı -baba ile, taşra (ülke) ile, toplumla ve yaşam ile kurulan -karmaşık, çözümsüz, belirsiz- ilişkilerin hatırlanmasını/düşünülmesini sağlar. Öztürk'ün (2018) belirttiği gibi, hareketli sırt sayesinde yaşanan sinematografik deneyim, seyircinin soru sormasına ve duygulanım yaşamasına imkan verir (40). Seyircinin kurmaca evrenden çıkıp özgürleşebileceği bu anın ortaya çıkmasında karakterin sırt aracılığı ile kimliksizleşmesinin de payı vardır. Film mekanını çözen bu etki, Magritte' in, Le Balcon de Manet (Manet'nin Balkonu, 1950) tablosunda da kişiler yerine tabutların kullanılması sayesinde gerçekleşir. Burada mekansızlığa gönderme yapan nesne, kişinin yerine geçer (Foucault, 2016: 41). Tablodaki tabutlar da figürlerdeki gizemi, ifadesizlikten ve konumlarından gelen belirsizliği ortaya koyar; tablodaki maddiliği çoğaltarak andırış etkisini güçlendirir. $\mathrm{Bu}$ durum, figürlerin sırtlarını göstermeye benzer bir eğilim ile bakışın yönünü ve yüzleri silmekle gerçekleşir. Yüz hatları silinen bir resmin duygusal boyuttan uzaklaşarak konuyu aşması ve tabloyu lekeler, renkler ve hareketlere indirgemesi gibi, sırt plan da ifadesizliği ve duygusal boyutu dışarıda bırakması ile filmi mecrasına indirger. Sinemada sırtın bu şekilde kullanımı, uzlaşımın tersi olan bir beden sergileme biçimidir.

Sinan'ın babası ile ilişkisini yüksek sesle sorgulamaya başladığı sahnelerden sonra gelen sırt takip planlar (Görsel 29, 30), hayaller ve gerçekler arasında bir yer değiştirmenin mekanı 


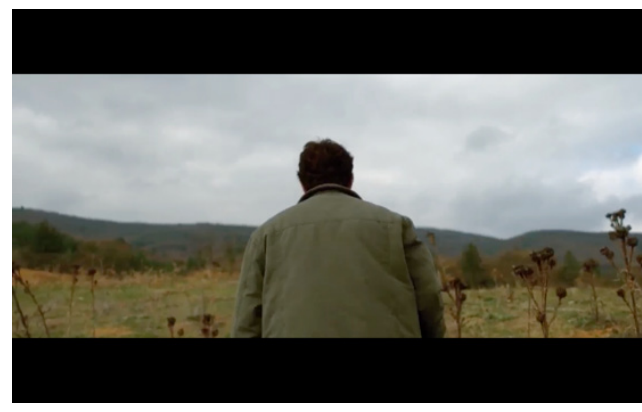

Görsel 29.

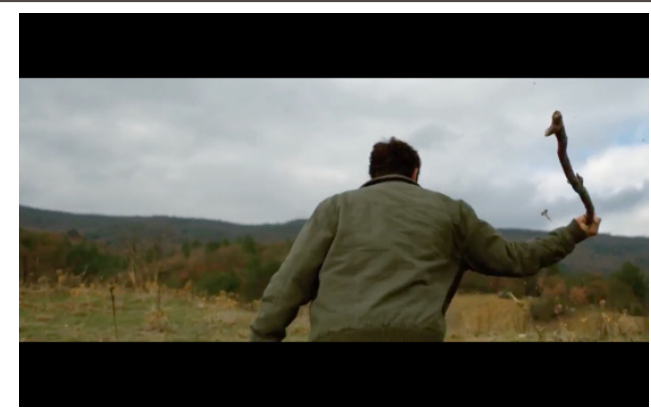

Görsel 30.

olur. Sırtın sessizliği bu ara mekandaki boşluktur. Seyirci ile sessiz ve esrarengiz sırt arasında bir bakışım alanı kurulur (Sayın, 2003: 10). Sırttaki çifte eksiklik, baba ile kurulan ilişkiyi (sıkışmışlıktan ağrılı bir iç yolculuğa varan) farklı düzeylerde kavramak için alan açar.

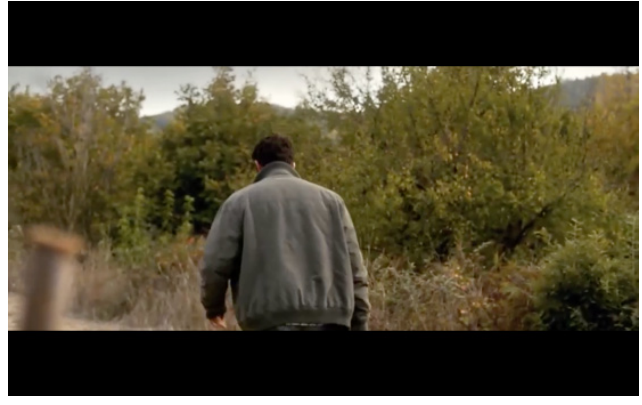

Görsel 31.

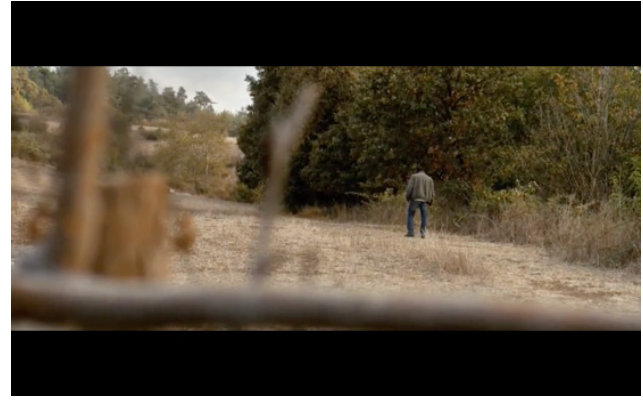

Görsel 32.

Denis Diderot'nun ortaya koyduğu, karakterin dördüncü duvar ile seyirciyi dişlaması olgusu; sırt takip planla bağlantılı olarak düşünüldüğünde üzerinde durulması gereken önemli bir ayrımı açığa çıkarır. Sinan, babasının kendini astığını düşündüğü sahnede (Görsel 31, 32), kapattığ 1 çitin ardından babasına baktıktan sonra, seyirciye ve babasına sırtını dönerek uzaklaşır. Tepki vermeden sırtını dönen karakterin ne düşündüğ ü ve ne hissettiği anlaşılamaz. Dehşet verici bir ana şahit olan Sinan, sırtını hem merak içindeki seyirciye hem de bir kurgu olarak filme dönmüş olur. Filmin kendi üzerine kapandığ 1 anlardan biri olarak yorumlanabilecek bu sahnede, görüntüye eklenen solukların yükselen sesi uzaktaki sirt ile birleştiğinde (mesafe düzeyinde görüntü ve ses arasında meydana gelen uyumsuzluğun da etkisiyle) bir karşılaşma anı yaratır; gerçeğin dehşeti, yüz planlarından çok daha etkili biçimde görünür olur. Bu noktada modern sinemada düşüncenin, arıza anlarında orta çıktığ1 hatırlanmalıdır (Öztürk, 2018: 218).

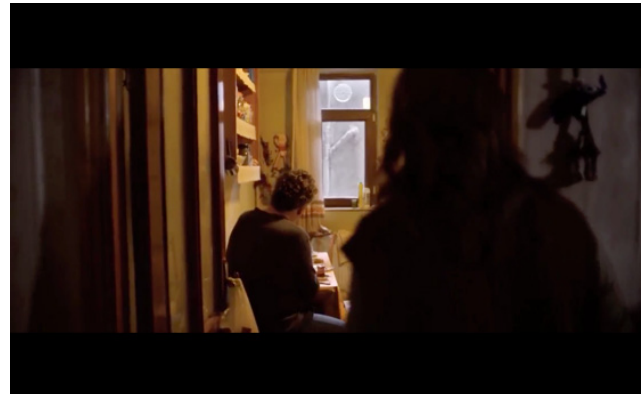

Görsel 33.

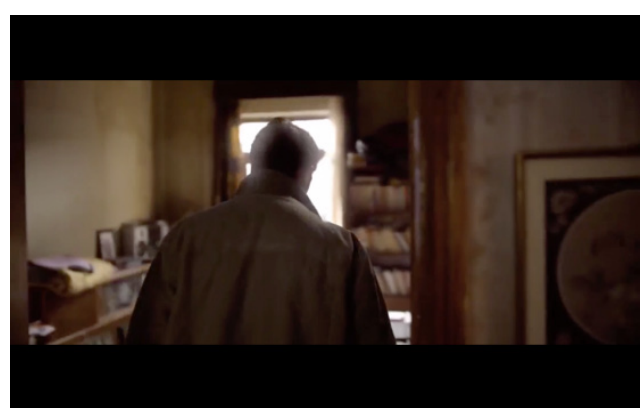

Görsel 34. 
Sırtlar ve sırtların karanlığı, evde iç içe hareket halindedir (Görsel 33, 34). Önce mutfakta karakterlerin kameraya sırtları dönük şekilde konuşmalarına, ardından koridordaki karakterlerin birbirlerine ve kameraya sırtlarını dönerek görüntü içindeki bakış alanlarını sürekli değiştirmelerine şahit olunur. Buradaki takip planlar, Manet'nin resminin açığa çıkardığı şaşkınlığa benzer bir izlenim ortaya koyar. Devinim halindeki formun ön plana çıktığı, figürlerin takibinin yarıda kesildiği ve içe içe geçtiği isabetli olmayan görüntüler, seyircinin beklentilerini boşa çıkarır. Bununla birlikte seyircide, yerini sürekli yeniden tayin etme arzusuna neden olur. Devam eden arayışı izleyen seyirci, oluşa tanıklık ederken, oluşun içinde yer değiştirir. Benzer şekilde, sırtın karanlık gölgeler olarak yer aldığı sırt takip planlar (Görsel 35- 40), sırtın kavranılamazlığı sayesinde bakışın tedirgin edici etkisini açığa çıkarır. Sırt, negatifliği ve var olamayışı ile seyirciye bakar. Başka bir ifadeyle sırtın yerine geçen seyirci kendi boşluğuna bakar. Burada seyirciye ayırılmış, gizli ve güvenli bir yer yoktur. Bununla birlikte, bu sahnelerdeki sırtların alanı, yansıtıcılık niteliği nedeniyle bir başvuru noktası olamaz. Bu nedenle, Magritte'in resimlerinde olduğu gibi, buradaki sırtların hareketi de benzeyişin aksine farklı yönlere hareket edebilen, yinelenebilen bir belirsizliği açı̆̆a çıkarır; bu yönüyle, Sinan'ın hikayesine eklemlenir.

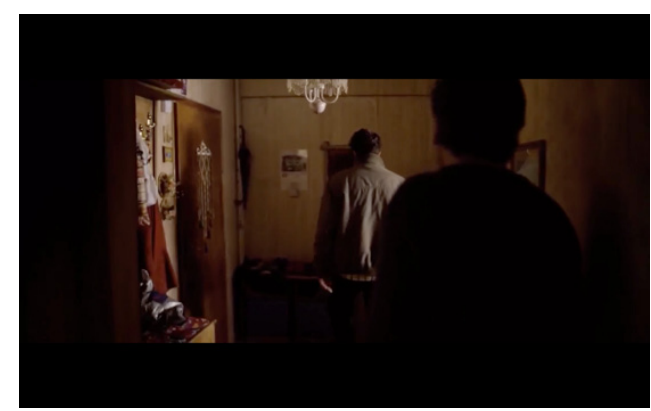

Görsel 35.

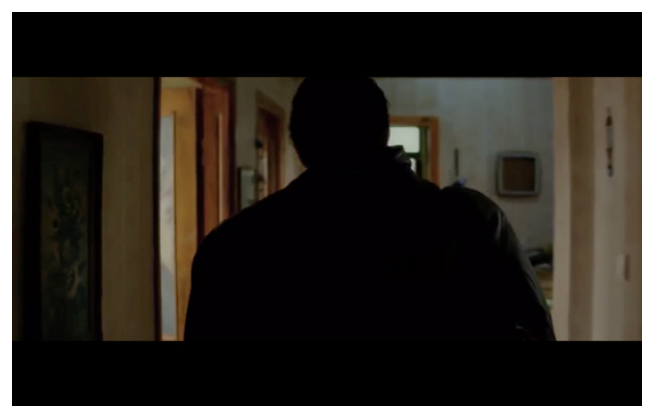

Görsel 37.

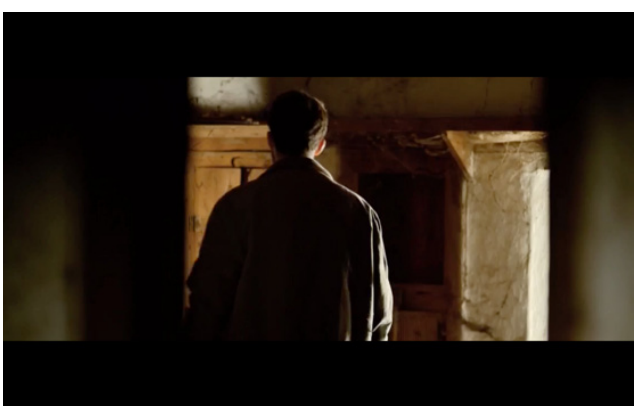

Görsel 39.

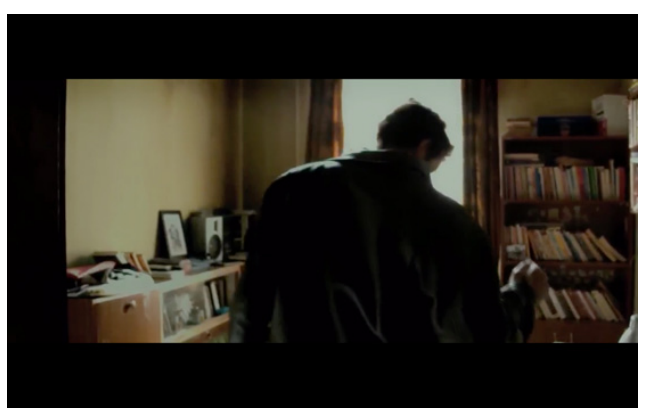

Görsel 36.

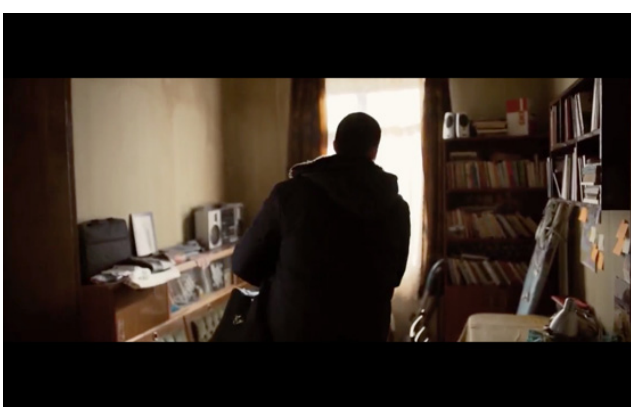

Görsel 38.

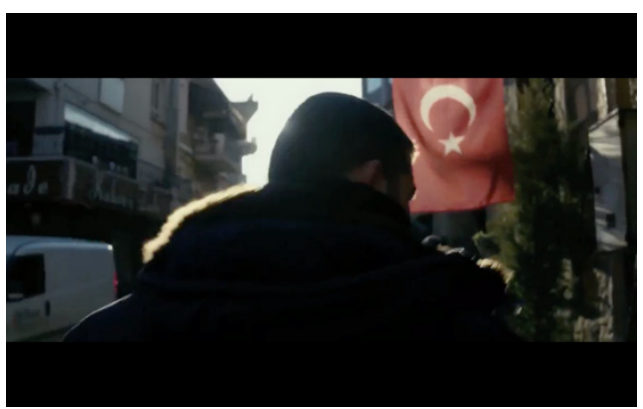

Görsel 40.

Foucault (2007), korku romanlarından hareketle, 18.yüzyılın ikinci yarısında karanlık korkusunun açığa çıktığını belirtir. Tam olarak görülemeyen kuytu ve izbe alanların suç ile 
ilişkilendirilmesi, anlatı yapısının temel öğesini oluşturur. Oysa bilinmezliğin alanlarının ortadan kaldırılması, modern düzen için gereklidir (93). Aydınlanma çağında, şeffaf olmama hali iktidar tarafından hoş karşılanmadığından "insandaki loş yerlerin" ortadan kaybolması önemli görülmüştür (94). Bu eksende, filmdeki karanlık sırtlar modernizmin karşıt söylemine eklemlenir. Söylem düzeyindeki karş1-işleyişin görünür olduğu bir diğer nitelik rastlantısallıktır. Çünkü rastlantısallık, maddesellik düzeyinde gerçekleşen olagelişin bir kategorisidir (Foucault, 1993: 29-30) Bu çerçevede, dağılma, birikme, karşılaşma ve ayrılma eylemleri ile nitelenebilecek ev içindeki sırtların maddeselliği ile birlikte var olan rastlantısal hareket, kurmacanın sorgulanabileceği bir alan yaratır. Film, sadece Sinan'ın sırtını değil, diğer karakterlerin sırtlarını da (Görsel 41, 42) takip ettirerek; engelleyici, perspektifi bozan, kaçış çizgisini engelleyen, yüzey etkisini güçlendiren, bir belirsizlik ve ifadesizlik alanı olarak sırt görüntüsünü açığa çıkarır.

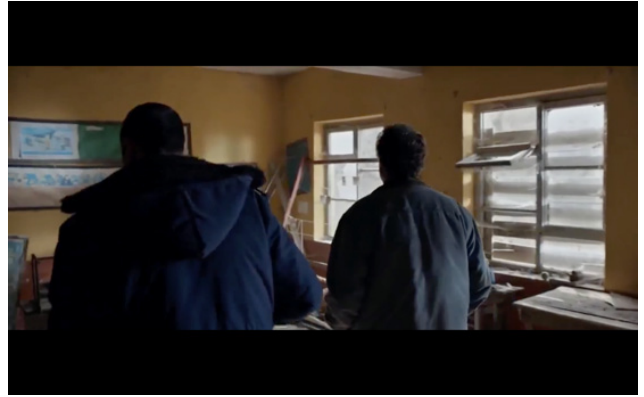

Görsel 41.

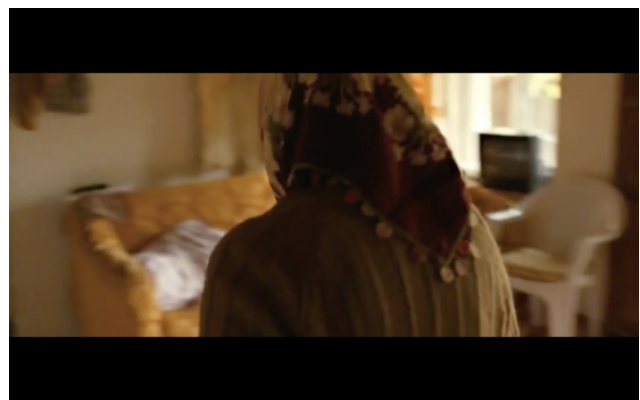

Görsel 42.

Sinan'ın Hatice ile karşılaştığı sahnede (Görsel 43, 44), kavranması güç duygular ve düşünceler, sırt figürünün gizemli varlığ 1 ve düzlügü ile seyircinin zihnini harekete geçirme potansiyeline sahip olur. Sinan' in sırtı ile birlikte çınarın gövdesi, anlatı evreninin düz yapısını seyirciye hatırlatır (Görsel 45, 46). Çınar ve sırt imgesi derinliği keserek, görüntünün yüzeyde çözülmesine neden olur (Thomas,2012c:169). Kaçış çizgisinin engellendiği bu görüntü, gözü

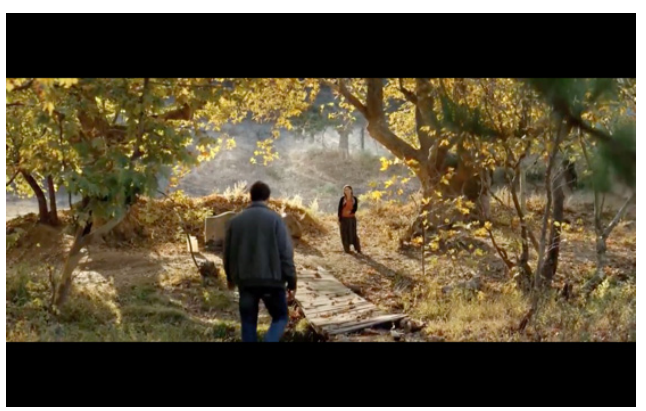

Görsel 43.

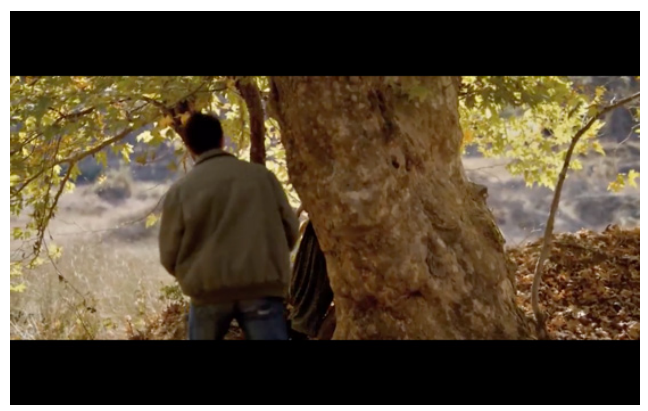

Görsel 45.

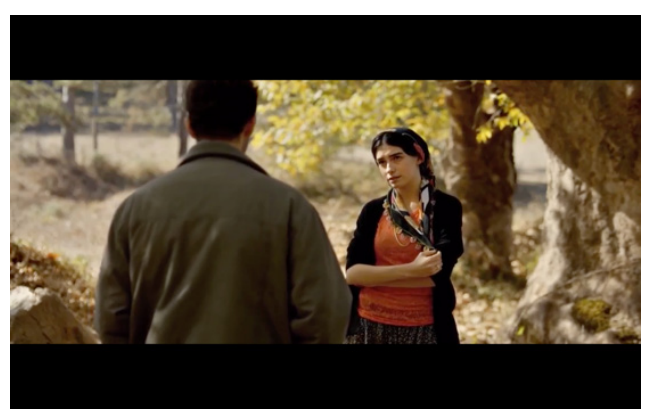

Görsel 44.

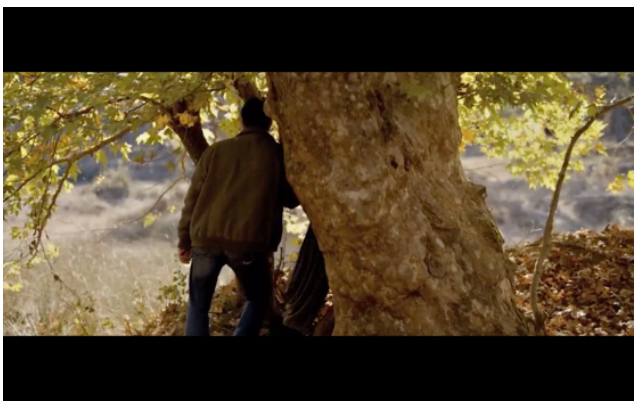

Görsel 46. 
bu iki yüzeye çeker. Ayrıca ikili konuşma sırasında 4 dakika 36 saniye gibi uzun bir süre boyunca (tüm uzlaşım kurallarına aykırı olarak), açı-karşı açı çekimi görülmez. Sinan'ın sırtı sabit, düz, yansıtıcı ve gizemli bir blok olarak -insanın karmaşıklığı ve bilinemezliği- ile seyircinin karşısındadır.

Sislerin görüntüyü kapladığı ve kameranın Sinan'ın sırtını takip ettiği sahnede (Görsel 47,48 ) sisler ve sırt, derinlik etkisini ortadan kaldırır. Soyutlamaya varan imge, düşünceyi açığa çıarır. Sinan'ın duygu dünyası; korkuları, kaygıları, arzuları seyirci tarafından da kendisi tarafından da tam olarak görülemeyecek ve gizemli kalacaktır. Filmin gösteremeyecekleri sırt imgesi ile vurgulanir. Belli belirsiz bir alan olarak Sinan'ın sırt, her an kaybolacak gibidir. Bu nedenle, bu sahnede sırta bakmak, Sinan ile diyalog kurmak anlamina gelir.

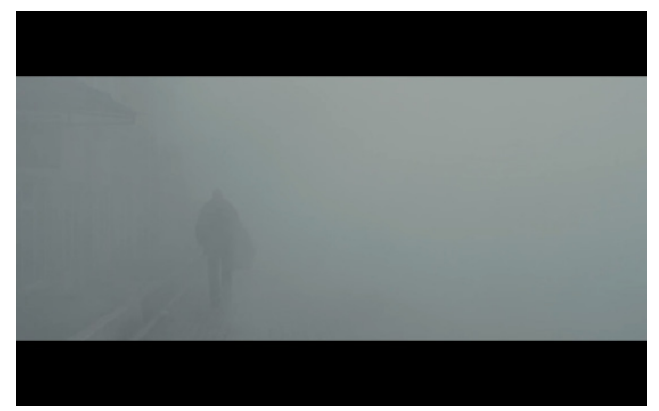

Görsel 47.

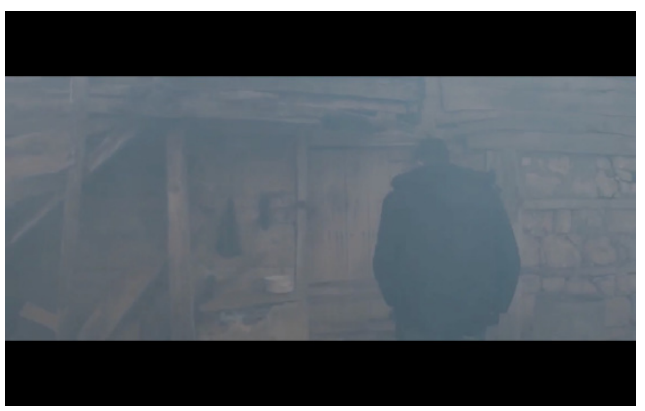

Görsel 48.

Üç karakterin sırtlarının uzun süre takip edildiği sahnede (Görsel 49-52) kamera, karakterlerin sesini görüntüden bağımsız biçimde seyirciye yaklaştırır. Karakterler kameradan uzaklaşsa bile, takibe devam edilir ve konuşmalar net olarak duyulmaya devam eder. Bu sekansta, görüntünün mesafesi ile uyumlu olmayan ses düzeyi, sırtların soyut imgelere dönüşmesini kolaylaştırır. Duyguların ifade alanı olan yüzlerin neredeyse hiç gösterilmemesi de bu etkiyi güçlendirir. İkinci olarak, önü gözükmeyen arka; seyirciye, bir yönünü göremediği imgenin eksikliği ile birlikte kendi hareketsizliğini de hatırlatır. Ayrıca, Magritte' in Ufka doğru Yürüyen Kişi tablosu da bu görüntülerle ilişkilendirilebilir. Orada lekeler yazı aracılığıyla söylemde bir yarık oluşturuyordu, burada ise sırttan çıkan seslere dönüşen diyaloglar, uzunluğu ve kalabalıklığı ile söylem ve imge arasındaki kopukluğa işaret eder. Bu arıza anı düşüncenin açığa çıkmasını sağlar (Öztürk, 2018: 218). Böylelikle film mekanı, konuşan sırtlar ile çözülmüş olur.

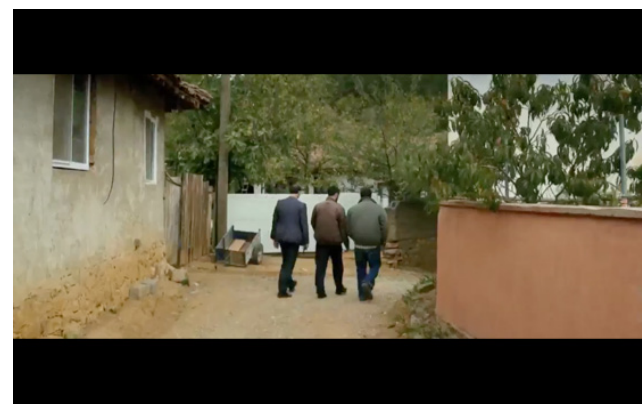

Görsel 49.

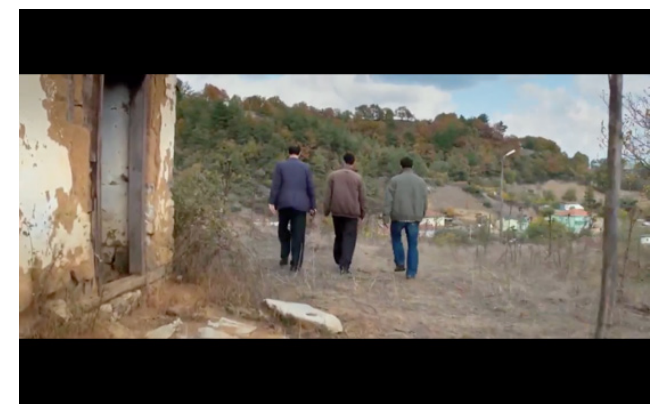

Görsel 50. 


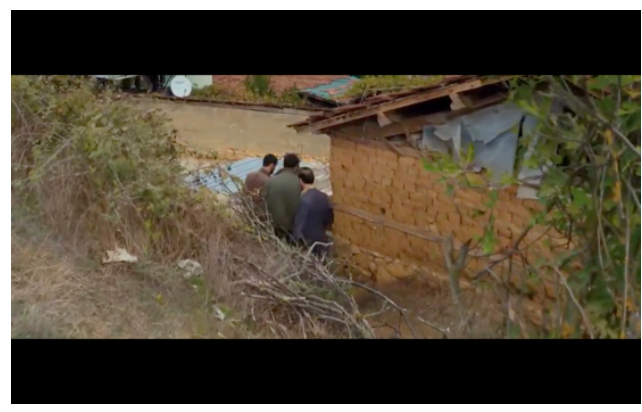

Görsel 51.

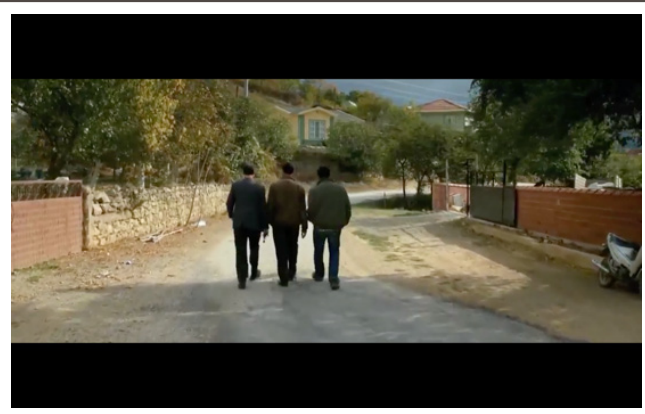

Görsel 52.

Bahsedilen planda sırt imgelerini, İslam geleneğinin imge ile ilişkisi üzerinden değerlendirmek de önemlidir. Tanrısal aşkınlık, benzeşimden uzak olarak tanımlanır: "(E)vrende hiçbir şey, Allah'ın dengi ya da benzeri değildir." (Sayın, 2003: 53). Musevilik inancında da benzer şekilde, imge yanıltıcıdır (Vasse, 2012: 115). Benzetmek ve göstermek, bir sırrı ortaya çıkarmak anlamına gelir; utanç verici, ayıp ve günah olarak kabul edilir. Seyretmeyi engelleyecek şekilde bakışların yere indirilmesi bu nedenle onaylanır. Sayın (2003), 13.yüzyıl sonrası Anadolu' da göz ile bakış arasına mesafe koyulduğunu dile getirir. Minyatür geleneğindeki ifadesiz yüzler bu mesafe ile ilgilidir (59-60). İmgeler, göz aracılı̆̆ıyla kendi hakikatlerini açığa çıkarır. İmgenin gösteremedikleri, göz ile görülür; çünkü tinsellik, teşhir edilmeyeceği için ancak gizlenebilir. Hakikat görünemez olandadır. Dolayısıyla, sırt temsil edilemez olana mutlak bir bağlılık olarak yorumlanabilir (Vasse: 115). Bu nedenle, bu uzun sırt takip plan sekansında sırtlar, Arslan'ın (2009) ifadesiyle "gerçekliğin varoluşsal açıklığının ve kapatılamazlığının imgeleri" (34) olur. Bakışının tatmin edilemediği bu görüntüler aracılığıyla, klasik temsil bozulur. İnanç, hakikat, hayatın anlamı, bilinemezlik, doğruluk gibi soyut kavramların tartışıldığı diyalog, sırtların soyutlaşan yüzeyinde gerçekleşir.

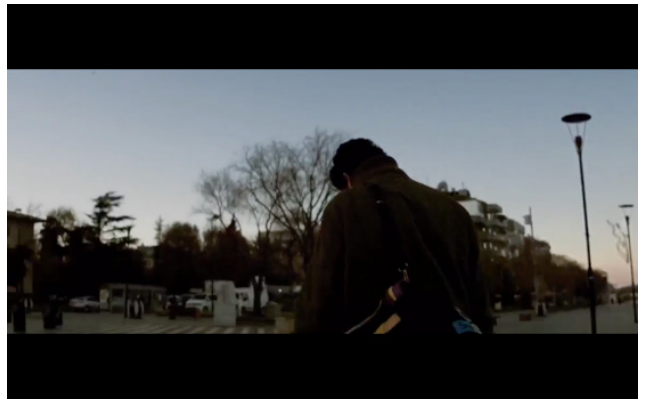

Görsel 53.

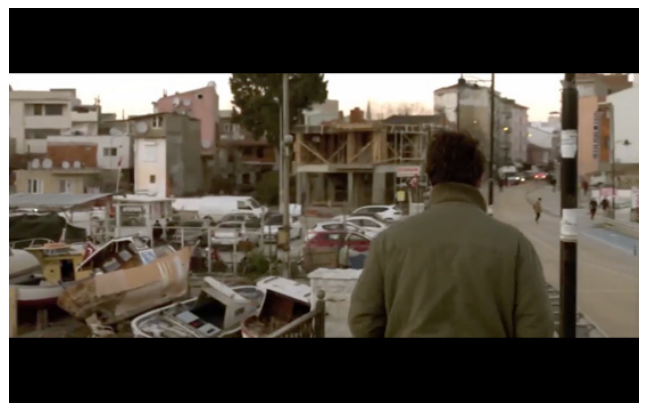

Görsel 54.

Bir karaltı olarak Sinan'ın sırtını gördüğümüz sahnede (Görsel 53), sola çevrinme (pan) hareketi ile kamera Sinan'1 takip eder. Sinan'ın sadece dış hatlarını görebildiğimiz iki boyutlu bir gölgeye benzeyen silüeti, arka plandaki bina ve ağaçlar ile iç içe / üst üste görülür. Sırt, zeminden ayırt edilemediğinden görüntüdeki derinlik etkisi ortadan kalkmış olur. Benzer şekilde, rüya sahnesi olan kaçış sekansında sokakların, kameranın takip hareketinin de etkisi ile iç içe geçmesi; binalar arasındaki mesafenin olduğundan kısa gösterilmesi ve geniş alan derinliği, Sinan'ın sırtını zemin ile birleştirir (Görsel 54, 55). Sinan, kaçmaya çalışırken geçtiği yolun /mekanın içine sıkışan ve bu nedenle de aslında kaçamayan bir karaktere dönüşür. İnşaat alanı içindeki sahnelerde de benzer biçimde, hâkî ceketli sırt, renk tonlarının yakınlığı nedeniyle mekandaki lekelerden birine dönüşür (Görsel 56). 


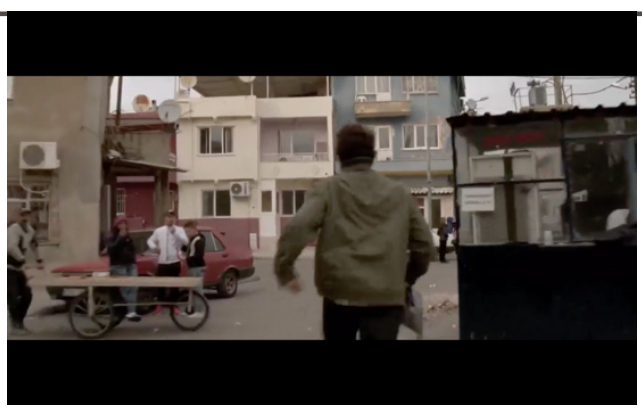

Görsel 55.

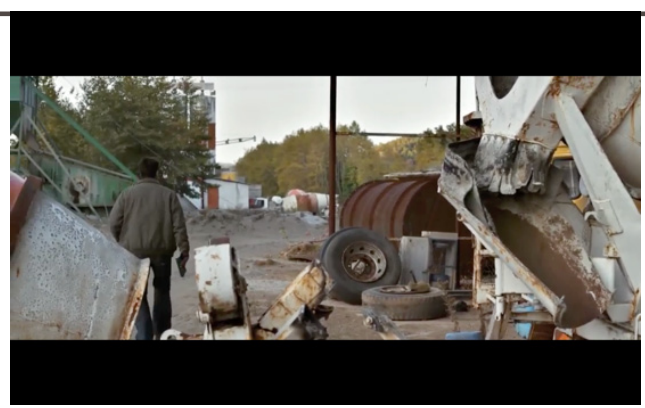

Görsel 56.

Robert Kolker (2011), insanın modern dünyadaki varoluş halinin, Serüven filminde, karakterlerin adanın parçası olarak görüntülendiği çerçeve düzenlemesi ile açığa çıkarıldığından bahseder (98). Benzer şekilde, Ahlat Ağacı filminde, sırttan görülen figür ve mekandaki nesnelerin birbirine karıştığ 1 soyutlama etkisine sahip olan düzenlemeler, Sinan'ın sürekli devam eden arayışı içindeki kaybolma halini görünür kılar. Öztürk'ün (2018) ifadesiyle sinema tam da bu şekilde felsefe üretir. Buradaki görüntüler, hayattan taşan unsurların yakalanmasını sağlamıştır. Filmin mekanı çözülerek, seyircinin ve filmin dünyası arasında yeni oluşlara imkan tanınmıştır (25).

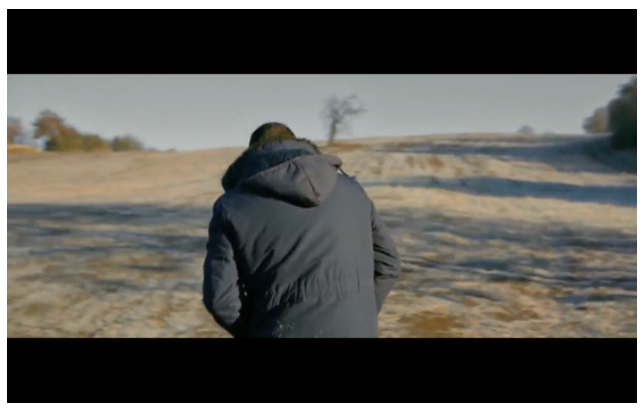

Görsel 57.

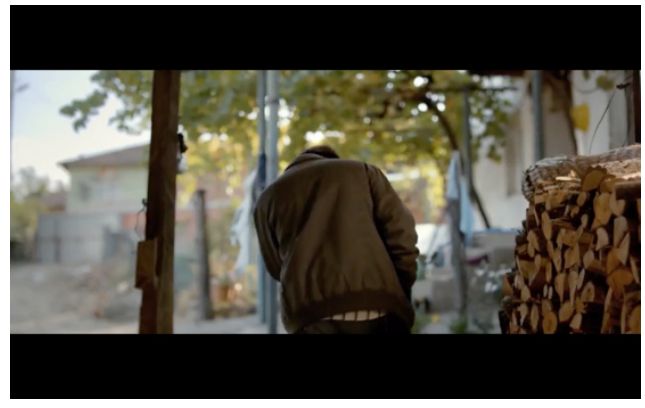

Görsel 58.

Sinan'ın sırtının eğik, biçimsiz gösterildiği planlarda (Görsel 57,58) sırtın, güce gönderme yapan genişliği ile kırılganlı̆̆ı simgeleyen eğikliği aynı anda ortaya konur (Roger, 2012: 51). Sırtın bir metafor olarak değerlendirilmesine de imkan verebilecek bu imgenin, bu çalışma için çift değerlilik niteliği ile yorumlanması anlamlı olur. Çünkü temsili bozan niteliklerden biri de, ikiliğin aynı figürde görünür kılınmasıdır. Eş zamanlılık, ifadeyi belirsizleştiren bir unsurdur.

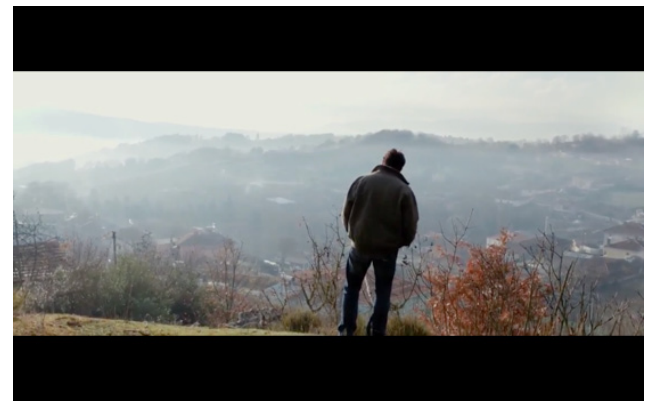

Görsel 59.

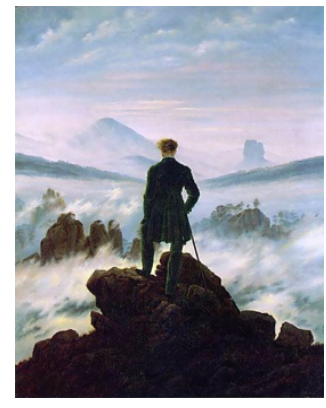

Görsel 60. Bulutlarn Üzerinde Yolculuk, 
Ahlat A $\breve{g} a c$ filminde yer alan sırt imgesinin (Görsel 59) Caspar David Friedrich resimleri ile benzerliği konusunda görüşler ortaya atılmış olsa da, bu çalışmada temel izlek olan filmin maddi evreninin ortaya koyulması açısından bu benzerliğin sorgulanması gerekir. David Friedrich' in sırtından görülen insanı uzaklaşma arzusu ile yeninin belirsizliği arasında manzara içinde yalnız bırakılmış bir kahramana dönüşür. Burada öznellik, doğa ile bütünleşme içinde erir (Banu, 2001: 113). Derin düşünceler içinde sırtlarından görülen figürler, romantizmin "yüce", "güzel" ve "melankoli" kavramları ile ilişkilendirilir (Aksakal, 2019). Romantizm ile bağlantısı, David Friedrich resmindeki sırt imgesini (Görsel 60), çalışmada ele alınan estetik modernizmin zemininden ayırır. Ayrıca, Ahlat A ğacı filminin Sinan karakterine olan mesafesi (burada anlatı düzeyinde) böyle bir benzerlik ilişkisinin kurulmasını engeller. Filmde, hayaller ve gerçeklerin bir aradalığı sezdirilirken bile, ikisi arasındaki uzaklığın vurgulandı̆̆ı; gerçekçi çatışmaları içeren (ülkenin toplumsal, kültürel ve ekonomik gerçekliği bağlamında) sorgulama zemininin belirgin olduğu görülmektedir.

\section{Sonuç}

Bu makalede, sinematografik bir biçim olarak sırt takip plan ile modernizmin estetik nitelikleri arasındaki ilişki incelenmiştir. Çalışmanın kavramsal çerçevesi, Foucault'nun Manet üzerine yaptığı Manet'nin Sanatı (1971) sunumu ekseninde oluşturulmuş; Magritte' in resimleri ile ilgili değerlendirmeleri de bu çerçeveyi desteklemiştir. Foucault'ya göre, Manet tuvalin mekansal özelliklerini vurgulamış, temsili ışık yerine gerçek ışığı kullanmış ve seyircinin tablo karşısındaki konumunu değiştirmiştir. Bakışın özgürleşmesi ile de bağlantılı olan bu yaklaşım sayesinde Rönesans döneminin klasik temsil biçimini bozan Manet, estetik modernizm sürecini başlatmıştır. Klasik temsili bozan unsurların incelenmesi, estetik modernizmin niteliklerinin de ortaya koyulmasina imkan vermektedir. Bunlar, derinlik duygusunun engellenmesi, soyutlama ve yüzey etkisi, tablonun önü ve arkasının mevcudiyetinin vurgulanması, tuvalin tekrarı, rastlantısallık, tamamlanmamışlık, bakışın talebi ve reddi, maddeselliğin çoğaltılması, mekanın çözülmesi, benzeyiş yerine andırışın tercih edilmesi olarak sıralanabilir. Bu nitelikler değerlendirildiğinde, bakışın değişimi ekseninde ifadesizlik-belirsizlik, yüzey-düzlük ve yer değiştirme kavramlarının ön plan çıktığı görülmüştür. Bu temalar, sinemada uzlaşımsal olmayan, klasik temsili kıran sırt takip planın nitelikleriyle örtüşmektedir ve estetik modernizm ile organik bir ilişki kurmaktadır. Klasik sinemada gerçekliğin izlenimi yanılsamasını yaratan, seyircinin bakışını denetleyen sırt takip planlar, modern sinemada filmin maddi evrenini açığa çıkaran, eleştirel ve özgürleştirici zihinsel imgelere dönüşmektedir. Modern sinemanın ayırt edici özelliği olan bakış ilişkilerindeki çatışma, yüze ve bakışa sahip olmayan sırt imgesini belirleyici bir güç olarak ön plana çıkarmaktadır. Ayrıca Lacan'ın "gerçek" olarak tanımladığı karşılaşmalar anı, sırt görüntüsüne zaten içkin olan -yüze sahip olmamasından kaynaklananeksiklik sayesinde yaratılmaktadır. Sıralanan bağlantı noktaları, modernizm, sırt ve bakış arasındaki ilişkinin temel düzeylerini de belirlemektedir.

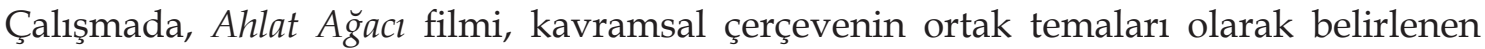
yüzey-düzlük, ifadesizlik-belirsizlik ve yer değiştirme kavramları ekseninde niteliksel olarak analiz edilmiştir. Buna göre, filmde kullanılan sırt takip planların, sırt imgesini bir yansitıcı alana dönüştürdüğü; yüzün eksikliği ile imgede açılan boşluğun bakışım alanı kurulmasına imkan verdiği; sırtın geçirimsiz yüzeyinin seyirciyi davet eden ve reddeden bir çift değerliliğe sahip olduğu; kontrol edilemeyen sırt imgesinin seyirciyi huzursuz ettiği ve seyircinin konumunu sorgulattığı görülmüştür. Sinan'ın sırt takip planlarının çoğu, ifadesizliği ile filmin mecrasını vurgulamakta, bakış alanlarının sürekli değişmesine neden olmakta; belirsizliği ve tamamlanmamışlığı ile seyircinin beklentilerini boşa çıkarmaktadır.

Telefonla konuşma sekansındaki uzun takip plan, hem hareket halindeki imgede bakışın engellenmesine hem de seyirci ile karakterin bakışı arasında bir istikrarsızlaşma yaratılmasına neden olmaktadır. Bu sayede imgenin anlatısallığını zayıflatarak düşünceye alan açmaktadır. 
Kameranın Sinan'ın sırtına yaklaştığı iki önemli sahnede sırt, gizlenen kör bir alan olarak görülmeyeni harekete geçirmekte; bakan belirsiz bir lekeye dönüşerek seyirciyi bilinmezlikle karşı karşıya bırakmaktadır. Bu planlar aracılı̆̆ıyla zamanda oluşan yarılma, gerçek' in dehşeti ile karşılaşılmasını sağlayarak sezgisel ve zihinsel bir tetikleyici haline gelmektedir.

Şehrin sokaklarındaki ve taşra mekanındaki arayış / kaçış sahnelerinde zeminle iç içe geçen Sinan'ın sırtı, iki boyutluluk ve düzlük etkisi ile filmin mekanını vurgulayarak seyirciye kurmaca yapıyı hatırlatmakta ve onu sorgulatmaktadır. Özellikle ev içi sahnelerinde, sırtların hareketi ile oluşa tanıklık eden seyirci, bu oluşun içinde yer değiştirdiği için seyreden rolü ile elde ettiği güvenli konumu kaybetmektedir. Bu planlarda sırtlar, derinliği engelleyerek ve kaçış çizgisini silerek görüntünün yüzeyde çözülmesine neden olmakta; esrarlı, belirsiz ve geçici varlıkları ile seyirciyi aktif zihinsel bir etkinliğin içine sokmaktadır. Filmdeki uzun üçlü takip plan, bakış ile göz arasına koyulan mesafeyi hatırlatmakta ve filmdeki sırt görüntüsünün Anadolu-İslam geleneğine eklemlenmesine imkan vermektedir. Burada soyutlamaya varan görüntü, bakışın eksikliği ile birlikte hakikatin açığa vurulamazlığını vurgulamaktadır.

Sonuç olarak, Ahlat A $\breve{g} a c ı$ filmindeki sırt takip planların bakış ekseninde ifadesizlikbelirsizlik, yüzey-düzlük ve yer değiştirme kavramları ile estetik modernizme eklemlendiği görülmüştür. Bu nitelikler filmin mekanının çözülmesine; filmin maddiliğinin açığa çıkmasına; sırtın zamansız mekanında yeni düşünceler üretilmesine ve böylelikle filmin zihinsel evreninin kurulmasına imkan vermektedir. Buradan hareketle, sırt takip planların katkısıyla oluşan zihinsel ilişkiler ağının, baba ile, taşra ile, ülke ile, toplumla ve yaşamla kurulan ilişkilerin tartışılabileceği devingen ve sınırsız bir hareket alanı olduğu söylenebilir.

\section{Kaynakça}

Aksakal, H. (2019, Kasım 22). Uçurumun kenarındaki ressam: Caspar David Friedrich. Eleştirel Kültür Dergisi. http:// www.ekdergi.com/ucurumun-kenarindaki-ressam-caspardavid-friedrich/

Arslan, Umut T. (2009). Aynanın sırları: Psikanalitik film kuramı. Kültür ve İletişim, 12(1), 9-38.

Artun, A. (2013). Baudelaire'de sanatın özerkleşmesi ve modernizm. Charles Baudelaire. Modern Hayatın Ressamı içinde (Çev. Ali Berktay). (7.basım). (s. 9-86). İstanbul: İletişim.

Atakan, Z.Ö. (Yapımc1) \& Ceylan N.B. (Yönetmen). (2018). Ahlat Ağacı. [Sinema Filmi]. Türkiye, Fransa, Almanya, Bulgaristan, Makedonya, Bosna Hersek, İsveç, Katar: Zeyno Film, Memento Films Production, Detail Film, RFF International, Sisters and Brother Mitevski, 2006 Produkcija Sarajevo, Film i Vast, Chimney Pot.

Bacon, F. (1949). Study from the human body [Resim]. National Gallery of Victoria, Melbourne, Avusturalya. https://www.ngv.vic.gov.au/explore/collection/work/3761/

Banu, G. (2001). L'homme de dos, peinture, théâtre. Paris: Adam Biro.

Baudry, Jean L. (1986). Ideological Effects of the Basic Cinematographic Apparatus. Philip Rosen (Ed.), Narrative, apparatus, ideology, A Film theory reader içinde (s.286-298). New York: Colombia University Press.

Bordwell, David. (1997). On The history Of film style. Cambridge, Massachusetts and London, England: Harvard University Press.

Bordwell, D., J. Steager ve Thompson K. (2005). The classical Hollywood cinema, Film style Emode of production to 1960. London: Routledge.

Bordwell, D. ve Thompson K. (2012). Film sanatı. (Çev. Ertan Yilmaz ve Emrah Suat Onat). 
Ankara: Deki.

Braunberger, P. (Yapımc1) \& Godard, J.L. (Yönetmen). (1962). Vivre Sa Vie [Sinema Filmi]. France: Les Films de la Pléiade.

Comolli, Jean L. (1974). Teknik ve İdeoloj. (Çev. Yakup Barokas). Çă̆daş Sinema Dergisi, (1), 9-29.

Çelik, T. (2018). Deleuze'ün zaman-imge kavramı ekseninde sinemada yakın plan: Sivas filmi odağında bir analiz. Deniz Bayrakdar (Ed). Türk film araştırmalarında yeni yönelimler 14, Sinema ve zaman-sinema ve sinema içinde (s. 61-84). İstanbul: Bağlam

Deleuze, G. (2003). İki Konferans. (Çev. Ulus Baker). İstanbul: Norgunk.

Delvaux, P. (1966). L'estacade [Resim]. Özel Koleksiyon. Banu, G. (2001). L'Homme de Dos, Peinture, Théâtre. Paris: Adam Biro

Durafour, Jean-M. (2012). Laura, voir l'image au dos du Film. Benjamin Thomas (Ed.), Tourner le dos, sur l'envers du personnage au cinéma içinde (s. 55-67). Paris: PUV, Université Paris 8, Saint-Denis.

Elsaesser, T., Hagener, M. (2014). Film kuramı, Duyular yoluyla bir giriş. (Çev. Berhan Sonar, Barış Yıldırım). Ankara: Dipnot.

Foucault, M. (1993). Ders özetleri, 1970-1982. (2. Bask1). (Çev. Selahattin Hilav). İstanbul: YKY.

Foucault, M. (2001). Kelimeler ve şeyler, İnsan bilimlerinin bir arkeolojisi (2. Bask1). (Çev. Mehmet Ali Kilıçbay). Ankara: İmge.

Foucault, M. (2006). Sonsuza giden dil. (Çev. Işık Ergüden). İstanbul: Ayrıntı.

Foucault, M. (2007). İktidarın gözü (2. Bask1). (Çev. Işık Ergüden). İstanbul: Ayrıntı.

Foucault, M. (2016). Bu bir pipo değildir. (12. Baskı). (Çev. Selahattin Hilav). İstanbul: YKY.

Foucault, M. (2018). Manet'nin Sanatı. Foucault, M., Talon-Hugon, C. ve Marie D. Manet, Velázquez ve estetik modernizm içinde (Çev. Savaş Kılıç). (s. 9-51). İstanbul: İletişim.

Foucault, M. (2018). Nedimeler: Velázquez'in Las Meninas'ı üstüne. Foucault, M., TalonHugon, C. ve Marie D. Manet, Velázquez ve estetik modernizm içinde (Çev. Savaş Kılıç). (s. 9-71). İstanbul: İletişim.

Friedrich, C.D. (1817). Der Wanderer über dem Nebelmeer [Resim]. Hamburger Kunsthalle, Hamburg, Almanya. https://www.hamburger-kunsthalle.de/en/nineteenth-century

Gris, F. (2012). Dos paysans. Tourner le dos à la caméra de Depardon. Benjamin Thomas (Ed.). Tourner le dos, sur l'envers du personnage au cinéma içinde (s. 139-153). Paris: PUV, Université Paris 8, Saint-Denis.

Gutting, G. (2010). Foucault. (Çev. Hakan Gür). Ankara: Dost Yayınları.

Hakim, Robert, Hakim Raymond (Yapımc1) \& Antonioni, M. (Yönetmen). (1960). L'Avventura. [Sinema Filmi]. İtalya, Fransa: Cino del Duca, Société Cinematographique Lyre.

Hakim, Robert, Hakim Raymond (Yapımc1) \&Antonioni, M. (Yönetmen). (1962). L'Eclisse. [Sinema Filmi]. İtalya, Fransa: Interopa Film, Cineriz, Paris Film Production.

Hammershøi, V. (1903-1904). Interiør. Ung kvinde set fra ryggen [Resim]. Randers Kunstmuseum, Randers, Danimarka. https:// www.randerskunstmuseum.dk/samling/ highlights/ 
Harkness, J. (2016). Önsöz. M. Foucault. Bu bir pipo değildir içinde. (12. Bask1). (Çev. Selahattin Hilav). İstanbul: YKY.

Kırel, S. (2018). Kültürel çalışmalar ve sinema. İstanbul: İthaki.

Koi, H., Mizoguchi, K. (Yapımc1) \& Mizoguchi,K. (1952). The life of Oharu [Sinema Filmi]. (1952). Japonya: Koi Productions, Shintoho Film Company.

Kolker, R. (2011). Film, biçim ve kültür. (Çev. Fırat Ertınaz ve Diğerleri). Ankara: Deki.

Kovács, András B. (2010). Modernizmi seyretmek, Avrupa sanat sineması, 1950-1980. (Çev. Ertan Yilmaz). Ankara: Deki.

Lacan, J. (2013). Psikanalizin dört temel kavramı, seminer 11. kitap. (Çev. Nilüfer Erdem). İstanbul: Metis Yayınları.

Magritte, R. (1928). L'apparition/Personnage Marchant Vers L'horizon [Resim]. Stuttgart Eyalet Galerisi, Stuttgart, Almanya. https://www.staatsgalerie.de/en/g/collection/digitalcollection/einzelansicht/sgs/werk/einzelansicht/70B32B694EC1C965237BA7A5571720CD. $\underline{\mathrm{html}}$

Magritte, R. (1937). La Reproduction Interdite [Resim]. Museum Bojimas Van Beuningen, Rotterdam, Hollanda. https://www.boijmans.nl/en/collection/artworks/4232/lareproduction-interdite

Magritte. R. (1955). Le Maitre d'école. [Resim]. Özel Koleksiyon. Banu, G. (2001). L'Homme de Dos, Peinture, Théâtre. Paris: Adam Biro.

Malevich, K. (1928-1929). To harvest (Matha and Vanka) [Resim]. The Virtual Russian Museum, Saint Petersbourg, Rusya. https://rusmuseumvrm.ru/data/collections/ painting/19 20/malevich ks na zhatvu marfa i vanka 1928 1929 zh 9492/index. php?lang=en

Marie, D. (2018). Ön yüz/arka yüz veya hareket halindeki seyirci. Foucault, M., TalonHugon, C. ve Marie, D. Manet, Velázquez ve estetik modernizm içinde (s.103-119). İstanbul: İletişim.

Manet, É. (1873). Le chemin de fer [Resim]. National Gallery of Art, Washington, Amerika. https://www.nga.gov/collection/art-object-page.43624.html

McGowan, T. (2012). Gerçek bakış, Lacan sonrası sinema kuramı. (Çev. Zeynep Özen Barkot). İstanbul: Say.

Metz, C. (2012). Sinemada anlam üstüne denemeler. (Çev. Oğuz Adanır). İstanbul: Hayalperest.

Mulvey, L. (2019). Görsel haz ve anlatı sineması üzerine. (Çev. Nigün Abısel). Büker S. ve Topçu, G. Y. (Ed.). Sinema, tarih kuram eleştiri içinde (s.201-218). İstanbul: İthaki.

Natan, B, Natan E. (Yapımc1) \& Grémillon, J. (Yönetmen). (1930). La Petite Lise. [Sinema Filmi]. Fransa: Pathé-Natan.

Orr, J. (1997). Sinema ve modernlik. (Çev. Ayşegül Bahçıvan). Ankara: Bilim ve Sanat.

Öztürk, S. (2016). 2. Sayımız çıarken: Gölgenin sineFilozofisi. SineFilozofi Dergisi, 1(2), 3-5.

Öztürk, S. (2018). Sinema felsefesine giriş, Film-yapımı felsefe. Ankara: Ütopya.

Öztürk, S. (2019a, Şubat). Mağara alegorisindeki mağaradan kurtuluşta sinemanın yeri.

Düşünbil Dergisi, (76), 6-9.

Öztürk, S. (2019b). Sinemada temsil anlayışına reddiye. SineFilozofi Dergisi, 4 (7), 3-9. 
Panofsky, E. (2017). Perspektif, simgesel bir biçim. (2.Baskı). (Çev.Yeşim Tükel). İstanbul: Metis.

Roger, P. (2012). Faire l'écran. Benjamin Thomas (Ed.). Tourner le dos, sur l'envers du personnage au cinéma içinde (s. 41-54). Paris: PUV, Université Paris 8, Saint-Denis.

Sayın, Z. (2003). İmgenin pornografisi. İstanbul: Metis.

Serceau, D. (2012). Au commencement, le dos. Benjamin Thomas (Ed.). Tourner le dos, sur l'envers du personnage au cinéma içinde (s.19-28). Paris: PUV, Université Paris 8, Saint-Denis.

Talon-Hugon, C. (2018). Manet ve Seyircinin Şaşkınlığı. Foucault, M., Talon-Hugon, C. ve Marie, D. Manet, Velázquez ve Estetik Modernizm içinde (s.75-101). (Çev. Savaş Kılıç). İstanbul: İletişim.

Tarr, B. (Yapımc1) \& Tarr, B. Ve Hranitzky, Á. (Yönetmen). (2000). Werkmeister Harmóniák [Sinema Filmi]. Macaristan, Almanya, Fransa: Goëss Film, Von Vietinghoff Filmproduktion, 13 Productions.

Thomas, B. (Ed.). (2012a). Tourner le dos, sur l'envers du personnage au cinéma. Paris: PUV, Université Paris 8, Saint-Denis.

Thomas, B. (2012b). Une félure dans le cristal, les Ténèbres de l'âme féminine d'Evgueni Bauer. Benjamin Thomas (Ed.). Tourner le dos, sur l'envers du personnage au cinéma içinde (s. 69-88). Paris: PUV, Université Paris 8, Saint-Denis.

Thomas, Benjamin, (2012c). Vitti Verso. Benjamin Thomas (Ed.). Tourner le dos, sur l'envers du personnage au cinéma içinde (s. 163-183). Paris: PUV, Université Paris 8, Saint-Denis.

Tunalı, İ. (2001). Estetik. (6. Basım). İstanbul: Remzi.

Vasse, D, (2012). Le dos et le Sol, de quelques dos dans le cinéma de Danièle Huillet et JeanMarie Straub. Benjamin Thomas (Ed.). Tourner le dos, sur l'envers du personnage au cinéma içinde (s. 111-122). Paris: PUV, Université Paris 8, Saint-Denis.

Wolf D. (Yapımc1) \& Van Sunt G. (Yönetmen). (2003). Elephant. [Sinema Filmi]. USA: HBO Film. 